\title{
The Microenvironment in Epstein-Barr Virus-Associated Malignancies
}

\author{
Geok Wee $\operatorname{Tan}^{1}$ (D), Lydia Visser ${ }^{2}$, Lu Ping Tan ${ }^{1,3}$ (D), Anke van den Berg ${ }^{2}$ and \\ Arjan Diepstra ${ }^{2, *(\mathbb{D})}$ \\ 1 Molecular Pathology Unit, Cancer Research Centre, Institute for Medical Research, Jalan Pahang, \\ 50588 Kuala Lumpur, Malaysia; geokwee@imr.gov.my (G.W.T.); luping@imr.gov.my (L.P.T.) \\ 2 Department of Pathology and Medical Biology, University of Groningen, University Medical Center \\ Groningen, Hanzeplein 1, code EA10, P.O. Box 30.001, 9700 RB Groningen, The Netherlands; \\ l.visser@umcg.nl (L.V.); a.van.den.berg01@umcg.nl (A.v.d.B.) \\ 3 Department of Medical Sciences, School of Healthcare and Medical Sciences, Sunway University, \\ Jalan Universiti, Bandar Sunway, 47500 Selangor Darul Ehsan, Malaysia \\ * Correspondence: a.diepstra@umcg.nl; Tel.: +31-50-3610404; Fax: +31-50-3619107
}

Received: 28 February 2018; Accepted: 11 April 2018; Published: 13 April 2018

\begin{abstract}
The Epstein-Barr virus (EBV) can cause a wide variety of cancers upon infection of different cell types and induces a highly variable composition of the tumor microenvironment (TME). This TME consists of both innate and adaptive immune cells and is not merely an aspecific reaction to the tumor cells. In fact, latent EBV-infected tumor cells utilize several specific mechanisms to form and shape the TME to their own benefit. These mechanisms have been studied largely in the context of EBV + Hodgkin lymphoma, undifferentiated nasopharyngeal carcinoma, and EBV+ gastric cancer. This review describes the composition, immune escape mechanisms, and tumor cell promoting properties of the TME in these three malignancies. Mechanisms of susceptibility which regularly involve genes related to immune system function are also discussed, as only a small proportion of EBV-infected individuals develops an EBV-associated malignancy.
\end{abstract}

Keywords: Epstein-Barr virus; tumor microenvironment; Hodgkin lymphoma; undifferentiated nasopharyngeal carcinoma; gastric carcinoma; immune escape; susceptibility

\section{Introduction}

Epstein-Barr virus (EBV) is a causal factor in various malignant diseases which usually originate from B cells or epithelial cells. Much is known about the transformative properties of latent EBV infection in the tumor precursor cells in these cancers. In addition to the possession of tumor cell-transforming properties, EBV can also influence the composition and the properties of the cells present in the tumor microenvironment (TME). The TME consists of non-transformed cells that are predominantly immune cells, giving the TME a reactive, inflammatory appearance. In addition, the TME contains chemokines, cytokines, and other bio-active substances. The TME is critically important in disease pathogenesis as the tumor cells need to evade anti-EBV immune responses and, in many instances, even receive support from TME cells. As only a small fraction of latent EBV-infected cells develop into a malignancy in a minority of EBV-infected individuals, it is likely that characteristics of the host immune system are associated with susceptibility, i.e., the likelihood of EBV-infected cells to develop into a malignancy.

In some EBV-associated cancers, little data on the TME is available because of low incidence of the disease (e.g., NK/T cell lymphoma), a minor TME component (e.g., Burkitt lymphoma), or a particularly heterogeneous immune deficiency (e.g., post-transplant lymphoproliferative disorder). 
In this review, we will discuss the composition and the function of the TME in the three most widely studied EBV-associated cancers, i.e., classical Hodgkin lymphoma (HL), undifferentiated nasopharyngeal carcinoma (NPC), and gastric carcinoma (GC). In western populations, approximately $30 \%$ of the HL cases are EBV positive (EBV+), whereas higher percentages are observed in tropical regions [1]. Virtually all undifferentiated nasopharyngeal carcinoma cases are positive for EBV [2], while only approximately $10 \%$ of gastric carcinoma cases are EBV+ [3]. As the interactions among EBV, tumor cells, and TME are numerous and intricate, we do not aim to give a comprehensive review of all published (possible) interactions. Rather, we will present an overview of mechanisms which we believe are most relevant in terms of impact and frequency. The mechanisms EBV uses to influence the TME will be described as well as mechanisms of immune escape and TME-induced tumor cell-promoting mechanisms. In addition, we will discuss studies on genetic susceptibility.

\section{Composition of the Microenvironment}

There is a large overlap in tumor cell-TME interactions between EBV + and EBV-negative cancers in both HL and GC and it is not always possible to indicate if certain characteristics are EBV specific. Therefore, we only state the differences between the TME of EBV+ and EBV-negative cases when there is available data. EBV+ HL, NPC, and EBV+ GC are often heavily infiltrated with immune cells, such as T cells, B cells, natural killer cells, dendritic cells, macrophages, myeloid-derived suppressor cells, neutrophils, eosinophils, and mast cells. Other non-immune cells derived from mesenchymal stem cells, such as fibroblasts and endothelial cells, are also present in the TME [4,5]. In HL, the TME cells usually outnumber tumor cells by $>100: 1$ and EBV+ HL tend to have a somewhat larger TME component than EBV-negative HL [1]. In EBV+ GC, the TME component is larger than in EBV-negative GC [6]. It should be noted that both the size and the composition of the TME in EBV+ HL, NPC, and $\mathrm{EBV}+\mathrm{GC}$ can be significantly variable among individual cases. This probably reflects different levels of attraction of the TME cells by chemokines as well as different levels of activation by cytokines and cell-to-cell interactions. Here, we describe the cells and chemokines which can be present in the TME. Whenever relevant, we make a distinction between tumor cell areas and stromal areas. The latter comprises areas of connective tissue, often with some degree of fibrosis. A schematic representation of TME cells in typical cases of EBV+ HL, NPC, and EBV+ GC is shown in Figure 1.

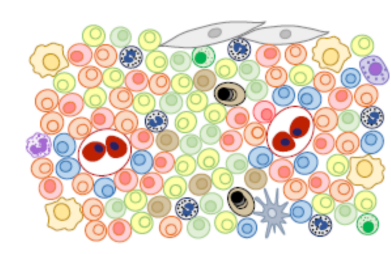

Hodgkin lymphoma

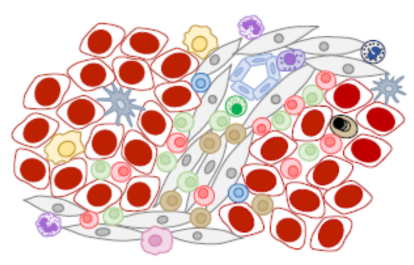

Nasopharyngeal carcinoma

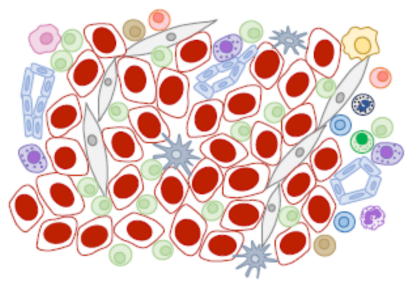

Gastric carcinoma

\begin{tabular}{|c|c|c|c|c|}
\hline \multicolumn{4}{|c|}{ Tumor microenvironment } & \multirow[t]{2}{*}{ Tumor cells } \\
\hline (๑) & $\mathrm{CD} 4+\mathrm{T}$ cells & (1) & Tumor associated macrophages & \\
\hline (๖) & Th1 cells & (a) & Myeloid derived suppressor cells & \\
\hline (2) & Th2 cells & 0 & Tumor associated neutrophils & \\
\hline (2) & Treg cells & 장 & Eosinophils & \\
\hline (2) & CD8+ $T$ cells & 8 & Mast cells & \\
\hline - & Natural killer cells & $\theta$ & Cancer associated fibroblasts & \\
\hline ๑ & B cells & 0 & Tumor associated endothelial cells & \\
\hline (1) & Plasma cells & 0 & Carcinoma cells & \\
\hline 拳 & Dendritic cells & (6) & Hodgkin and Reed-Sternberg cells & \\
\hline
\end{tabular}

Figure 1. Composition of the tumor microenvironment in EBV-associated malignancies. The cellular composition of the microenvironments of typical cases of EBV+ Hodgkin lymphoma, undifferentiated nasopharyngeal carcinoma and EBV+ gastric carcinoma are shown. 


\subsection{T Cells}

In HL, T cells form distinct layers around the tumor cells, called rosettes. Most of these rosetting $\mathrm{T}$ cells are $\mathrm{CD} 4$ positive (CD4+), consisting of either T helper 2 (Th2) cells that are involved in inducing humoral immune responses or regulatory $\mathrm{T}$ (Treg) cells that mediate immune suppression [7-9]. A number of chemokines from the CC sub-family are involved in the recruitment of Treg cells and Th2 cells in the TME and are probably responsible for the formation of the rosettes. These chemokines, namely CCL17 (TARC), CCL20 (MIP3A), and CCL22 (MDC), are expressed by Hodgkin tumor cells [10,11]; in EBV+ HL, expression of CCL20 is induced by Epstein-Barr virus nuclear antigen 1 (EBNA1) [11]. Both CCL17 and CCL20 attract CC chemokine receptor 4 positive (CCR4+) Treg and Th2 cells to HL tumor cells in vitro [12]. CD4+ Th1 cells can induce cytotoxic immune responses and CD8+ T cells are located outside the rosettes, further away from the Hodgkin tumor cells as compared to the Th2 and Treg cells $[5,13,14]$. The presence of EBV elicits a higher number of infiltrating CD4+ T cells [8] and CD8+ T cells [15], including activated cytotoxic CD8+ T cells (CTLs) [13,15]. This can be explained by the tumor cell-specific production of the CXC-family chemokines CXCL9 and CXCL10 which attract CXCR3+ Th1 cells [16,17]. EBV is also associated with the presence of additional T regulatory 1 ( $\operatorname{Tr} 1)$ cells [8] which are induced Treg cells that secrete IL-10. In contrast, the number of natural thymus-derived Treg cells is not associated with EBV status in HL [7,13].

In NPC, T cells are the main component of the TME [18-20]. Natural Treg cells and CD8+ T cells are frequently present in the stroma and occasionally in the tumor cell area [19,21]. It appears that only a subset of the CD8+ T cells has cytotoxic potential [21]. Not much is known about the precise composition of CD4+ T cell subsets (Th1, Th2, Treg cells, etc.) in NPC. Th1 cells are present and attracted by CXCL9 [22] and CXCL10 [16]. Some NPC cases contain CCL20-expressing tumor cells which attract CCR6-expressing Treg cells, as has been shown both in vitro and in vivo [23,24]. In contrast to HL, CCL17 expression is absent in NPC [25] and, to the best of our knowledge, CCL22 expression has not been explored in NPC.

In GC, T cells are distributed among tumor cells and are also present in the stroma [26-29]. Similar to EBV+ HL, EBV triggers a significantly higher infiltration of CD8+ T cells and CTLs in EBV+ GC [6,28-31]. The number of infiltrating CD8+ T cells is always more abundant in EBV+ GC than the number of infiltrating CD4+ T cells, often up to a ratio of 10:1 [6]. RNA-seq analysis of GC samples revealed a significant association of a CTL signature with EBV load [32]. GC cells secrete CCL20 [33], CCL22 [31], and CCL17 (in a minority of cases) [31]. EBV+ GC cells produce more CCL22 and attract more Treg cells than EBV-negative GC in vitro [31].

In short, $\mathrm{T}$ cells are an important component of the TME in the three EBV-associated malignancies and these $T$ cells are actively recruited by chemokines that are produced by the tumor cells. The numbers of different subsets within the $\mathrm{T}$ cell population varies substantially between individual cases. Although there is some overlap, between EBV+ and EBV-negative cases, there is an overall tendency of higher involvement of Th1 and CD8+ cells in EBV-associated diseases; this is most prominent in EBV+ GC.

\subsection{Natural Killer Cells}

Natural killer (NK) cells can rapidly kill target cells, including virus-infected cells; however, they have not been widely studied in the TME of EBV-associated malignancies. Significantly higher percentages of NK cells were reported in seven cases of EBV+ HL as compared to seven cases of EBV-negative HL ( $8 \%$ vs. 1\%) [13]. In NPC, only a low number of NK cells is present, ranging from $1 \%$ to $9.5 \%$ and are located mainly in the stroma [18,20,34]. In EBV+ GC, NK cells are undetected [6]. The number of NK cells in EBV-associated cancers is perhaps lower than expected which might be a result of the inhibition of their recruitment and activation. 


\subsection{B cells and Plasma Cells}

Upon activation, B cells can mature into plasma cells and secrete antibodies to tag pathogens or infected cells for immune destruction. In EBV+ HL, NPC, and EBV+ GC, B cells are present but usually in lower numbers than T cells. In HL, B cells, and plasma cells can be present, but it is unclear to what extent these cells are specifically attracted or resident cells of the involved lymph node. In NPC, B cells are present at varying percentages $[18-20,35]$ and they mostly reside in the stroma $[19,36]$. In EBV+ GC, only scattered B cells are found, usually in the stroma [6,26]. Little is known about the role of these seemingly normal B cells in the TME of EBV-associated cancers.

\subsection{Dendritic Cells}

Dendritic cells (DCs) are professional antigen presenting cells that present antigenic peptides to CD4+ T cells in the context of Human Leukocyte Antigen (HLA) class II. In cancers, the activation and maturation of DCs into different functional subsets depends largely on the cytokine milieu in the TME. In EBV+ HL and NPC, high numbers of DCs are found to infiltrate tumor cell areas [37]. In NPC, mature DC cells are seen predominantly within the tumor cell area with a few in the surrounding stroma $[38,39]$. Higher numbers of DCs are present in EBV+ GC compared to EBV-negative GC [34]. In EBV+ GC, mature DCs are in close proximity to tumor cells and appear to have a positive correlation with the abundance of lymphocyte infiltration [40].

\subsection{Tumor-Associated Macrophages}

Macrophages polarize into diverging phenotypes with different functions depending on signals from the microenvironment. Macrophages activated by IFN- $\gamma$ and lipopolysaccharide are classified as M1 macrophages with a pro-inflammatory function that supports Th1 responses (CD8+). In contrast, M2 macrophages exhibit anti-inflammatory functions and promote Th2 responses (humoral). Tumor-associated macrophages (TAMs) are macrophages that are recruited to the TME by chemokines such as CCL2 (MCP-1) and CCL5 (RANTES) [41,42]. In HL, significantly higher numbers of TAMs are observed in EBV+ HL as compared to EBV-negative HL [43-47]. In NPC, M1-polarized macrophages are found in both tumor cell areas and stroma [48,49], while M2-polarized macrophages, when present in high density, are often distributed in the stroma [50]. Latent membrane protein 1 (LMP1) regulates the expression of CCL2 and CCL5 in NPC cells in vitro [51], both of which can recruit TAMs. In GC, macrophages are more commonly seen in the stroma [26] and one study reported a significantly lower number of TAMs in EBV+ GC as compared to EBV-negative GC [52].

\subsection{Myeloid-Derived Suppressor Cells}

Myeloid-derived suppressor cells (MDSCs) are derived from immature myeloid cells which failed to differentiate into mature cells of myeloid lineage, such as macrophages, dendritic cells, and granulocytes. MDSCs exhibit strong immunosuppressive activities. Circulating MDSCs are detected in the blood of HL [53,54], NPC [55,56], and GC patients [57-59]. MDSCs have been observed in the stroma of NPC [55] and in GC [59-61]. In NPC, LMP1 is associated with the presence of MDSCs, and the function of LMP1 in inducing MDSCs was validated in vitro [62].

\subsection{Granulocytic Cells}

Granulocytic cells consist of neutrophils, eosinophils, and mast cells. Varying numbers of neutrophils are present in HL and they are attracted by IL- 8 which is produced by reactive cells including TAMs. Neutrophils are also associated with tumor cell necrosis probably because of their main function as phagocytic cells. In NPC, neutrophils are commonly present in the stroma [34] and one study reported the presence of tumor-associated neutrophils in approximately $10 \%$ of NPC cases [63]. In EBV+ GC, some cases have a low number or no neutrophils while some have neutrophils present at extreme numbers [64]. Eosinophils are granulocytes that are usually involved in immune 
responses against parasitic infection and allergy [65]. The presence of eosinophils in the TME is fairly common in cancers. Tissue eosinophilia is reported in a subset of HL, NPC, and GC cases [43,66-71]. In HL, it is more prominent in EBV-negative cases, but it can also occur in EBV+ HL [67].

Mast cells are granulocytes present in tissue which release histamine in allergic reactions. In EBV+ $\mathrm{HL}$, mast cells are scattered diffusely within the lymphocyte background [72]. Higher numbers of mast cells are more commonly seen in the NS subtype $[66,72,73]$. This corresponds to the association of the NS subtype with fibrosis; mast cells are involved in promoting fibrosis [74]. In NPC, mast cells are observed in the stroma $[34,75]$. In GC, mast cells are distributed near blood vessels and may play a role in angiogenesis $[76,77]$.

\subsection{Cancer-Associated Fibroblasts}

Cancer-associated fibroblasts (CAFs) are activated fibroblasts in the TME that have a disparate immunophenotype compared to quiescent fibroblasts. In HL of the NS subtype, fibroblasts are involved in forming fibrous septae. In NPC, CAFs surround tumor cell nests [78] and their density varies among NPC cases [79]. CAFs are also present in EBV+ GC [80]. In epithelial malignancies, CAFs may play an important role in promoting tumor progression, e.g., by secreting proteases that degrade the extracellular matrix $[81,82]$.

\subsection{Endothelial Cells}

Endothelial cells form a layer on the internal surface of blood and lymphatic vessels and can be involved in inflammation, fibrinolysis, and angiogenesis [83]. In tumor neoangiogenesis, they are activated by signals from tumor cells such as VEGF. In EBV+ HL, VEGF is produced by the tumor cells in the majority of cases [84]. A study on NPC demonstrated that VEGF expression is induced by LMP1 $[78,85]$. In addition to their main role in neoangiogenesis, endothelial cells can also promote recruitment of $\mathrm{T}$ cells when they are stimulated by Hodgkin tumor cell-derived lymphotoxin- $\alpha$, also known as tumor necrosis factor- $\beta$ (TNF- $\beta$ ) [86].

\section{Immune Escape Mechanisms}

Individuals who are latently infected by EBV have mounted adaptive, T cell-dependent anti-viral immune responses that keep the number of infected host cells low. In the majority of individuals, this prevents the development of EBV-driven malignancies. These malignancies can only occur if the tumor precursor cells have escaped from these $\mathrm{T}$ cell responses. Many escape mechanisms are present at the time of diagnosis considering the T cell-rich TME. These mechanisms are related to antigen presentation by HLA as well as antigen-dependent activation of T cells. The complex antigen-dependent interaction between tumor cells and T cells can be affected at many different levels, as explained in more detail below.

\subsection{Latency Expression Patterns}

$\mathrm{EBV}+\mathrm{HL}, \mathrm{NPC}$, and EBV+ GC display a type II latency expression pattern of EBV proteins that includes expression of EBNA1 and LMP2. LMP1 is always expressed in EBV+ HL, at variable levels in NPC (50-80\%) [87], and is usually absent in EBV+ GC (10\%) [88]. BARF1 is highly expressed in NPC and EBV+ GC [89] but not in EBV+ HL [90]. The immunodominant EBNA3A, 3B, and 3C proteins are not expressed; this can be considered as a mechanism of immune escape. Another well-known immune escape mechanism is the glycine-alanine repeat domain that is present in the EBNA1 protein; this protein inhibits efficient ribosomal translation and strongly inhibits its peptides from being presented through HLA class I [91]. However, EBNA1-specific CTL responses do occur in EBV+ cancer patients, albeit at low frequencies [92]. In addition, EBNA1-specific CD4+ T cell responses are common and appear to be effective in killing EBV-infected cells [93]. Although T cells targeted to LMP1 occur infrequently, LMP2-specific CD8+ T cells are often detectable at the time of diagnosis in NPC [94]. In short, although the EBV+ tumor cells are not as immunogenic as lytically infected cells, they are still 
capable of eliciting EBV-specific immune responses. In addition, these tumor cells are also threatened by immune responses directed to neoantigens, i.e., antigens derived from proteins that have been altered, such as by gene mutations.

\subsection{Expression of HLA}

One straightforward mechanism employed by tumor cells to prevent the presentation of antigenic peptides is to downregulate expression of HLA on the tumor cell membrane. This occurs in EBV+ HL in which $\sim 30 \%$ of cases the tumor cells have lost expression of HLA class I and $\sim 30 \%$ of cases have lost expression of HLA II (only partly overlapping) [95]. This is fewer than is seen in EBV-negative $\mathrm{HL}$; this is surprising because one would expect that anti-EBV immune responses would result in a stronger selective pressure to downregulate HLA. However, it has been proposed that HLA expression is necessary for the surrounding lymphocyte infiltration which can nurture tumor cell growth as well as survival. HLA class I and II are even more strongly expressed in Hodgkin tumor cells in $\sim 40 \%$ of EBV+ HL cases when comparing with normal B cells. This highly increased expression may be induced by LMP1 or by changes in chromatin organization by PML (that can be disrupted by EBNA1) and/or special AT-rich sequence binding protein 1 (SATB1) [96,97]. There is less data on NPC, but it has been reported that complete loss of HLA class I expression occurs in approximately $20 \%$ of cases and partial loss in an additional 58\% of cases [98]. Another study showed a loss of HLA class I expression in $50 \%$ of NPC cases [99]. Other changes in the antigen presenting machinery may alter the quality and quantity of presented peptides as well. This has been shown for HLA-DM, a crucial molecule in the presentation of antigens in the HLA class II pathway. HLA-DM is necessary for the displacement of the invariant chain CLIP peptide from HLA class II to allow binding of antigenic peptides. In the absence of HLA-DM, HLA class II will be expressed at the cell surface but only with the non-immunogenic CLIP protein. In $40 \%$ of EBV+ HL, HLA-DM expression is missing while cell surface HLA class II expression is present [95], indicating that the HLA class II expression is not functional. In HL, another mechanism that probably prevents antigen recognition by CD8+ $\mathrm{T}$ cells is the formation of CD4+ $\mathrm{T}$ cell rosettes. These rosettes form a physical barrier between $\mathrm{CD} 8+\mathrm{T}$ cells and the tumor cells.

\subsection{Co-Stimulation}

In addition to antigen recognition, $\mathrm{T}$ cells need a second co-stimulatory signal to become fully activated. This second signal can also be inhibitory. These so-called immune checkpoints, are important in maintaining immune homeostasis. Co-inhibitory receptors, such as programmed death 1 (PD-1), cytotoxic T lymphocyte antigen 4 (CTLA-4), and lymphocyte activation gene 3 (LAG-3), control T cell responses. Many tumors take advantage of the co-inhibitory receptors to suppress anti-tumor responses. Interaction of PD-1 with its ligands PD-L1/PD-L2 inhibits T cell proliferation and induces apoptosis of tumor-specific T cells. It also promotes differentiation of CD4+ T cells into Tregs and thereby increases the resistance of tumor cells against attack from CTLs. PD-L1 has been shown to be highly expressed in tumor cells and TME cells including TAMs in EBV+ HL, NPC, and EBV+ GC [100-103]. The increased expression of PD-L1 and PD-L2 is partially caused by the amplification of chromosome 9p24.1 in EBV+ HL and EBV+ GC $[104,105]$. In addition, LMP1 has been shown to upregulate PD-L1 expression in NPC [103]. CTLA-4 also negatively regulates T cell activation by binding to the $T$ cell costimulatory receptors CD80 and CD86. In NPC, CTLA-4 can be overexpressed by tumor cells [106]. Thus, overexpression of PD-L1/PD-L2 and CTLA-4 can induce T cell exhaustion and is a means of immune escape in EBV-associated cancers.

\subsection{Excretion of Immunosuppressive Agents}

IL-10 is an immunosuppressive cytokine that inhibits Th1 cells and CTLs. Expression of IL-10 has been shown to be higher in EBV+ HL, NPC, and EBV+ GC compared to their EBV-negative counterparts [107-110]; higher secretion of IL-10 corresponds to lower numbers of CTLs in NPC and EBV+ GC [109,111]. In EBV+ malignant B cells, LMP2A induces expression of IL-10 [112]. In NPC, 
one study showed the presence of IL-10-producing B cells in the TME [35]. Moreover, NPC cells express annexin II, a ligand for DC-specific intercellular adhesion molecule-3-grabbing nonintegrin (DC-SIGN) to stimulate increased production of IL-10 by DCs [113]. IL-10 can also be produced by $\operatorname{Tr} 1$ cells, TAMs, and MDSCs. Another immunosuppressive cytokine TGF- $\beta$ can induce Treg and Th17 cell differentiation from naïve CD4+ T cells as well as polarize both macrophages and neutrophils to support tumor cells [114]. Blockade of TGF- $\beta$ can increase the activation of CD8+ T cells into CTLs [114]. In HL, TGF- $\beta$ is produced by tumor cells [115] and by MDSCs which are activated through a constant stimulation by the tumor cells [116]. Galectin- 1 is a soluble beta-galactoside binding lectin that is secreted in about half of EBV+ HL cases as well as in NPC cases [117]. It reduces infiltration of CD8+ T cells in the TME and impairs immune responses against LMP1 and LMP2 [118]. In NPC, galectin-9 produced by tumor cells was shown to induce apoptosis in Th1 cells [119]. Overall, immune suppressive agents produced by tumor cells and/or by cells in the TME are important components of EBV-associated diseases.

\subsection{Innate Immune Responses}

In addition to escaping from antigen-specific immune responses, EBV+ tumor cells also need to escape from innate immune responses. EBV+ tumor cells can prevent adaptive immune recognition by downregulation of HLA class I; however, these tumor cells are then at risk of NK cell-mediated killing. Indeed, NK cells can sense the loss of HLA expression by lack of ligation of killer inhibitory receptors. HLA-G is a non-classical HLA molecule that can inhibit NK cell activation when expression of classical HLA class I is lost. HLA-G expression has been observed in HLA class I negative EBV + HL cases [120] and in NPC as well [121]. Indoleamine 2,3-dioxygenase (IDO1) expression can be regulated by the Epstein-Barr virus-encoded small RNAs (EBERs) and has an immune suppressive effect on NK cells as well as CTLs [32]. In addition, PD-L1, IL-10, and TGF- $\beta$ contribute to NK cell inhibition [122].

\section{Tumor Cell Promoting Mechanisms}

There is sufficient evidence that the tumor cells in EBV+ cancers depend on the TME for certain stimulatory factors. It is extremely difficult in both EBV+ HL and NPC to make xenografts of primary tumor tissue, indicating that the tumor cells need contacts and factors from their microenvironment. It is likely that tumor cell promoting factors are already important during the early stages of pathogenesis. Subsequently, mutations can occur that ensure constitutive activation of signalling pathways, e.g., involving nuclear factor kappa $b(\mathrm{NF}-\mathrm{kB})$ and TNFAIP3 in EBV+ HL [123-126]. Mutations in the NF- $\mathrm{kB}$ pathway also occur in NPC $[127,128]$ and lead to constitutive activation of NF- $\mathrm{kB}$. The most important pathways involved in tumor cell promotion in EBV-associated malignancies are the NF- $\mathrm{kB}$, the janus kinase/signal transducers and activators of transcription (JAK/STAT), and microtubule-associated protein kinase/extracellular signal-regulated kinase (MAPK/ERK) pathways. Significant redundancy exists in the mechanisms that activate these pathways, emphasizing their important role in pathogenesis.

\subsection{Stimulation of $N F-\kappa B$}

The NF- $k B$ pathway can be divided into canonical and non-canonical pathways. The canonical pathway promotes inflammation, cell proliferation, and cell survival; it also involves the B cell receptor (BCR), Toll-like receptors, and TNF family receptors. RelA is a specific component of this pathway. Normally, activation of $B$ cells is triggered by the binding of the BCR to antigen. Loss of BCR expression is lethal to normal B cells but occurs in HL tumor cells. The EBV-encoded LMP2A is a functional homologue of the BCR and may thus rescue the tumor cells in EBV+ HL. LMP2A is also known to be expressed in NPC $[129,130]$ and in a proportion of EBV+ GC as well [131]. Decoy receptor 3 (DcR3) is a member of the tumor necrosis factor superfamily (TNFSF) family which can bind to TNFSF14 and FasL as well as prevent apoptosis. DcR3 is expressed in HL but no association with EBV was found [132]. In contrast, $75 \%$ of LMP1+ NPC tissues overexpress DcR3. DcR3 is upregulated in vitro by LMP1 and enhances migration and invasion via PI3K and NF- $\mathrm{kB}$ [133]. The non-canonical NF- $\mathrm{kB}$ pathway 
regulates lymphoid development, has anti-inflammatory activity, is activated via CD30 and CD40 amongst others, and is dependent on RelB. Overexpression of CD30, which is ubiquitous in EBV+ HL tumor cells [134], can lead to spontaneous NF-kB activation [135]. In addition, CD30L is found on eosinophils and mast cells in HL and may activate CD30 by cell-to-cell interactions [136,137]. CD40 is expressed on the tumor cells in EBV+ HL [138,139], NPC [36], and EBV+ GC [140]. In EBV+ HL, expression of IL-10 by the tumor cells can enhance the expression of CD40L on T cells [141]. In EBV+ GC, the virus activates CD40 signalling and promotes survival and proliferation [142]. Thus, signals derived from the TME can stimulate the non-canonical NF-kB pathway. In addition, LMP1 mimics the function of CD40 and interacts with TRAFs to activate NF-kB [51,62,143].

\subsection{Stimulation of JAK/STAT}

The JAK/STAT pathway is stimulated via cytokine receptors. Upon binding of the cytokine to the receptor, dimerization takes place and JAK proteins are phosphorylated. This leads to phosphorylation and dimerization of STATs which move to the nucleus and function as transcription factors. The JAK/STAT pathway is involved in proliferation, survival, invasion, and inflammation. In EBV+ HL, the JAK/STAT pathway is constitutively activated [144] by amplification of JAK2 [145] or, in some cases, mutations in the inhibitors PTPN1 [146] and SOCS1 [147]. In addition to stimulation via NF-KB, LMP1 also interacts with JAK3 and thereby activates STAT1 in B cells [148]. Interestingly, in NPC, LMP2A downregulates NF-kB and STAT activity and represses LMP1 expression, showing that mechanisms in epithelial cells are different from those in B cells [149].

\subsection{Cytokine Receptors}

In EBV+ HL, receptors for IL-3, IL-6, IL-7, IL-9, IL-13, IL-15, and IL-21 are present on the tumor cells. Most cytokines are also produced by the Hodgkin tumor cells, whereas some are produced exclusively by other cells in the microenvironment such as IL-3 by eosinophils, mast cells, and T cells. IL-6, IL-9, and IL-21 are produced by Hodgkin tumor cells and by T cells in the TME [150,151]. In EBV+ HL, IL-13 activates STAT6 and induces expression of LMP1 [152]. EBNA1 binds to the IL6R at the transcription start site and induces IL-6R expression in EBV+ B cells [153]. IL-6R expression has been reported in NPC and IL-6 is produced by tumor cells in the TME, acting as a growth factor and resulting in STAT3 activation [154]. Both leukemia inhibitory factor (LIF) and its receptor (LIFR) are expressed in NPC. LMP1 enhances LIF expression thereby promoting proliferation of the tumor cells in NPC [155]. CXCR4 is expressed on the membrane of NPC cells but is also found in the nucleus, possibly playing a role in cancer development and progression [156] as well as metastasis [157]. CXCR4 expression and its translocation to the nucleus is regulated by LMP1 [158]. LMP1 induces tyrosine sulfation of CXCR4; this is likely associated with cell motility and invasiveness [157]. The ligand for CXCR4, SDF1, is also expressed in NPC [158]. Another cytokine, IL-1 $\beta$, is expressed in EBV+ GC; in vitro experiments have shown that it acts as an autocrine growth factor [159].

\subsection{Stimulation of $M A P K / E R K$}

The MAPK/ERK pathway can be stimulated by binding of soluble or membrane bound factors to receptor tyrosine kinases (RTKs). The cascade includes different members of the MAPK/ERK family and affects proliferation and differentiation of cells. In EBV+ HL, no activating mutations in any of the RTKs have been found thus far, whereas in NPC, mutations in MAPK/ERK activators occur in 13-15\% of cases $[128,160]$. In HL, several RTKs are usually co-expressed although less frequently in EBV+ HL [161]. Platelet-derived growth factor receptor alpha (PDGFRA) is expressed in 75\% of all HL cases, including EBV+ HL, and it is activated by autocrine stimulation [162]. Discoidin domain receptor 1 (DDR1) is found in 75\% of EBV+ HL cases and is induced by LMP1 [163]. Expression of the other RTKs, i.e., DDR2, EphrinB1, RON, TRKA, and TRKB, are each found in approximately $30 \%$ of cases. Type I collagen I is present in sclerotic bands in NS type HL and can bind to DDR1 as well as to DDR2 [161]. It increases survival and induces protection from apoptosis [163]. Nerve growth factor (NGF) produced 
by mast cells can bind to TRKA [161]. C-Met expression is found in HL [164,165], NPC [166], and EBV+ GC [167], while its ligand hepatocyte growth factor (HGF) is produced in dendritic cells in HL and in the interstitial tissue surrounding the tumor in NPC [166]. HGF is expressed in some GC, but it is unknown whether this includes EBV+ GC. Both latent EBV infection and signaling induced by CD40L on T cells can induce c-Met expression in B cell lymphoma [168-170]. Hodgkin tumor cells express IGF-1R [171], and IGF-1 expression can be found in NPC [172] and EBV+ GC [173]. TNF receptor signals are conveyed by TRAF1 which is expressed in $40 \%$ of NPC cases and in all LMP1+ NPC cases. EBERs can induce expression of IGF-1 in NPC and EBV+ GC cell lines and act as an autocrine growth factor $[172,173]$. Additional factors that are regulated by EBERs can have tumor growth supportive effects $[172,173]$.

\section{Susceptibility to EBV-Associated Malignancies}

The host immune response against EBV is thought to be associated with the risk of development of EBV-associated malignancies. One underlying hypothesis is that a less efficient host immune response leads to a higher number of EBV-infected cells, thus increasing the pool of potential tumor precursor cells. An alternative hypothesis is poor clearance of EBV-infected cells by the immune system during all or some stages of malignant transformation. Both potential mechanisms are present in the context of primary immune deficiency and immune suppression, e.g., in post-transplant lymphoproliferative disease. In the general population, the efficiency of the host immune response against EBV is determined in part by genetic factors [174]. This efficiency has been assessed by measuring EBV-specific antibody titers or by EBV copy numbers. Several single nucleotide polymorphisms (SNPs) have been associated to these measurements based on candidate gene approaches, e.g., variants within IL-10 [175]. Most of these associations have not been confirmed in independent studies, although associations with the HLA class II region are reported recurrently. Genome-wide association studies (GWAS) in large cohorts revealed associations of anti-EBNA-1 antibody levels with HLA-DRA, HLA-DRB9, and HLA-DRB1 amongst others [176]. In a Mexican-American family-based study, two independent loci within the HLA class II region were identified to be associated with anti-EBNA-1 antibody levels. The most likely candidates for these associations are HLA-DRB1 and HLA-DQB1 [176]. In a French family cohort of 424 individuals, high anti-EBNA-1 levels were associated with a SNP in the HLA class II region [177]. In two large studies, suggestive associations with SNPs and specific genomic regions were observed for EBV copy numbers in cohorts of more than 900 and 1700 lymphoblastoid cell lines (LCLs). These LCLs were derived from individuals with different ethnicities, and clear differences were observed for EBV copy numbers and ethnicity [178].

\subsection{Genetic Associations in $E B V+H L$}

There are many studies on genetic associations with susceptibility to EBV-associated cancers and some of the observed associations overlap. For a more detailed overview of all currently available association studies, we refer to the extensive review published by Houldcroft and Kellam [174]. In 2005, we studied associations within the HLA region in EBV-stratified Dutch HL patients and showed two distinct associations, i.e., one with EBV+ HL in the HLA class I region and one with EBV-negative HL in the HLA class III region [179]. The association of EBV+ HL with the HLA class I region was confirmed in subsequent GWAS studies $[180,181]$. This association was shown to be related to the HLA-A gene, with HLA- $A^{*} 01$ as a risk and HLA-A*02 as a protective type for the development of EBV+ HL $[182,183]$. A modeling of HLA associations by means of direct HLA typing in combination with selected SNPs from GWAS revealed HLA-A*01 and HLA-B*37:01 as risk alleles and HLA-DRB1*15:01 and DPB1*15:01 as protective alleles [184]. As HLA-A*01-restricted immune responses to EBV latent peptides have never been encountered in the general population, the risk effect of this allele may be explained by a decreased ability of CD8+ T cells to recognize EBV-infected cells. In contrast, HLA-A*02 responses to EBV latent peptides, mainly LMP2A, are common and the protective effect of HLA-A*02 has been studied in EBV+ HL tissue. In (relatively rare) HLA-A*02 positive cases, the number of CD8+ 
T cells was significantly higher than in cases without HLA-A*02 [185]. In a Northern Chinese EBV+ HL population, no associations were observed for HLA-A*01 and HLA-A*02 using 2-digit HLA typing. Additional sequence-based typing indicated that the HLA-A*02:07 allele predisposes to EBV+ HL, while the other HLA-A*02 alleles do not [186].

\subsection{Genetic Associations in NPC}

As with EBV+ HL, the most striking associations in GWAS studies in NPC are found within the HLA region, with HLA-A as the most prominently predicted candidate gene [187-190]. Several studies confirmed the strong association with HLA-A, e.g., a study in Chinese NPC cases showing a strong association with HLA-A and HCG9 [190]. Focusing specifically on the HLA region, the associations were linked to the peptide binding motif of HLA-A*11:01, with a second independent

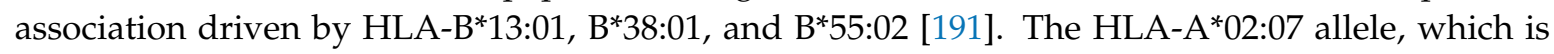
common in Eastern Asia, has also been shown to predispose to the development of NPC [192]. In a more recent study, the associated HLA-A amino acid variants and SNPs confirmed the correlation with HLA-A*11:01 and, to a lesser extent, with HLA-A*02:07 [188]. Interestingly, the HLA-A*02:07 association with NPC is shared with EBV+ HL in Chinese populations, but there is no association with HLA-A*01, probably a result of the low frequency of this HLA-A type in Chinese populations. A second gene mapping close to the HLA-A gene, the G-protein coupled receptor subunit gamma aminobutyric acid $b$ receptor 1 (GABBR1), has also been linked to NPC susceptibility [193]. However, because of a strong linkage in the HLA region, it is not clear whether this is an independent association or not. Other non-HLA loci identified in smaller NPC cohorts include integrin- $\alpha 9$ (ITGA9) and the IL1 receptor antagonist (IL-1RN). Variants in ITGA9 are strongly associated with a risk of NPC in a Malaysian Chinese population [194]. For some integrins, a link with EBV cell entry and infection have been proposed [195] which might explain the observed association with ITGA9. In a Portuguese population of NPC cases, a strong association was observed with variants in IL-1RN, which is an endogenous inhibitor of the inflammatory interleukin $1 \beta$ [196]. In a search for additional non-HLA loci, the top 1000 SNPs identified by Bei et al. [187] were validated in two steps, using more than 2000 cases in the first step and more than 7000 in the second step [197]. This revealed two associated loci: TERT-CLPTM1L, which is involved in telomere function, and CIITA, the master regulator of HLA class II expression. A meta-analysis on four NPC GWAS studies also found the TERT-CLPTM1L association [198]. Another recent study reported pathogenic heterozygous germline variants in the macrophage-stimulating 1 receptor (MST1R) gene in early onset (age $\leq 20$ years) NPC [199]. MST1R is expressed in macrophages and ciliated epithelial cells in the nasopharynx; defects in this gene may impact innate immunity and motility of cilia.

\subsection{Genetic Associations in Gastric Carcinoma}

In gastric cancer, GWAS studies are usually performed on mixed patient groups including both $\mathrm{EBV}+$ and EBV-negative cases. As only a minority of the cases are EBV+, it is difficult to dissect associations that are linked to EBV. Serological typing of HLA in $110 \mathrm{EBV}+$ and 155 EBV-negative cases revealed associations with HLA-B59, DQ3, DR9, and DR11 [200]. In a targeted gene approach study, a comparison of $30 \mathrm{EBV}+$ cases to $120 \mathrm{EBV}$-negative cases revealed an association for promoter polymorphisms at the TNF- $\alpha$ and IL-10 gene loci [201]. Additional targeted approach studies revealed associations with Filaggrin (FLG), a filament-associated protein that binds to keratin fibers, in EBV+ GC, and EBV-negative GC [202]. Glypican-4 (GPC4), a member of the heparan sulphate proteoglycan family, was associated with EBV+ GC [203].

Thus, with some exceptions, most of the susceptibility associations in HL, NPC, and GC involve genes that are components of the immune system, which theoretically may result in (partial) immune escape. Protective gene variants are present in a lower number of patients but can still occur, as EBV uses multiple mechanisms to escape from immune responses. 


\section{Concluding Remarks}

The TME is an essential component in the pathogenesis of EBV-associated malignancies. These cancers result from a combination of failing immune control and tumor cell nurturing immune responses. Interactions between cells in the TME and tumor cells are complex and vary between individual cases with the same cancer type. On the other hand, there is also a large overlap in mechanisms among different EBV-associated cancer types, as outlined in this review. Determining which EBV-induced mechanisms are most important is challenging as none of the mechanisms are present or dominant in all cases. In addition, malignant transformation itself also will have an impact on interactions between the tumor cells and cells in the TME. Research in this field is hampered by the lack of clinically or biologically recognized precursor lesions for EBV-associated malignancies as well as the absence of both animal and in vitro models that accurately recapitulate the human in vivo situation. The interactions between TME and tumor (precursor) cells are part of a highly dynamic process in which both components adapt to each other. Thus, mechanisms that are important early in pathogenesis may have been overtaken by other mechanisms at the time of diagnosis. Nonetheless, it is important to realize that there is a high variability between cases at diagnosis, especially when designing novel treatment strategies that aim to activate or disrupt the TME as a means of eradicating EBV+ tumor cells.

Acknowledgments: This work is supported by the Ministry of Health Malaysia (NMRR-16-1439-30762).

Conflicts of Interest: The authors declare no conflict of interest.

\section{References}

1. Swerdlow, S.H.; Campo, E.; Harris, N.L.; Jaffe, E.S.; Pileri, S.A.; Stein, H.; Thiele, J. (Eds.) WHO Classification of Tumours of Haematopoietic and Lymphoid Tissues, 4th ed.; IARC Press: Lyon, France, 2017; ISBN 9789283244943.

2. El-Naggar, A.K.; Chan, J.K.C.; Grandis, J.R.; Takata, T.S.P. (Eds.) WHO Classification of Head and Neck Tumours, 4th ed.; IARC Press: Lyon, France, 2017; ISBN 9789283224389.

3. Shibata, D.; Weiss, L.M. Epstein-Barr virus-associated gastric adenocarcinoma. Am. J. Pathol. 1992, 140, 769-774. [CrossRef] [PubMed]

4. Young, L.S.; Yap, L.F.; Murray, P.G. Epstein-Barr virus: More than 50 years old and still providing surprises. Nat. Rev. Cancer 2016, 16, 789-802. [CrossRef] [PubMed]

5. Scott, D.W.; Gascoyne, R.D. The tumour microenvironment in B cell lymphomas. Nat. Publ. Gr. 2014, 14, 517-534. [CrossRef] [PubMed]

6. Van Beek, J.; Zur Hausen, A.; Snel, S.N.; Berkhof, J.; Kranenbarg, E.K.; Van De Velde, C.J.H.; Van Den Brule, A.J.C.; Middeldorp, J.M.; Meijer, C.J.L.M.; Bloemena, E. Morphological evidence of an activated cytotoxic T-cell infiltrate in EBV-positive gastric carcinoma preventing lymph node metastases. Am. J. Surg. Pathol. 2006, 30, 59-65. [CrossRef] [PubMed]

7. Alvaro, T. Outcome in Hodgkin's Lymphoma Can Be Predicted from the Presence of Accompanying Cytotoxic and Regulatory T Cells. Clin. Cancer Res. 2005, 11, 1467-1473. [CrossRef] [PubMed]

8. Morales, O.; Mrizak, D.; François, V.; Mustapha, R.; Miroux, C.; Depil, S.; Decouvelaere, A.V.; Lionne-Huyghe, P.; Auriault, C.; de Launoit, Y.; et al. Epstein-Barr virus infection induces an increase of T regulatory type 1 cells in Hodgkin lymphoma patients. Br. J. Haematol. 2014, 166, 875-890. [CrossRef] [PubMed]

9. Marshall, N.A.; Christie, L.E.; Munro, L.R.; Culligan, D.J.; Johnston, P.W.; Barker, R.N.; Vickers, M.A. Immunosuppressive regulatory $\mathrm{T}$ cells are abundant in the reactive lymphocytes of Hodgkin lymphoma. Blood 2004, 103, 1755-1762. [CrossRef] [PubMed]

10. Van den Berg, A.; Visser, L.; Poppema, S. High Expression of the CC Chemokine TARC in Reed-Sternberg Cells. Am. J. Pathol. 1999, 154, 1685-1691. [CrossRef]

11. Baumforth, K.R.N.; Birgersdotter, A.; Reynolds, G.M.; Wei, W.; Kapatai, G.; Flavell, J.R.; Kalk, E.; Piper, K.; Lee, S.; Machado, L.; et al. Expression of the Epstein-Barr virus-encoded Epstein-Barr virus nuclear antigen 1 in Hodgkin's lymphoma cells mediates up-regulation of CCL20 and the migration of regulatory T cells. Am. J. Pathol. 2008, 173, 195-204. [CrossRef] [PubMed] 
12. Ishida, T.; Ishii, T.; Inagaki, A.; Yano, H.; Komatsu, H.; Iida, S.; Inagaki, H.; Ueda, R. Specific recruitment of CC chemokine receptor 4-positive regulatory $\mathrm{T}$ cells in Hodgkin lymphoma fosters immune privilege. Cancer Res. 2006, 66, 5716-5722. [CrossRef] [PubMed]

13. Wu, R.; Sattarzadeh, A.; Rutgers, B.; Diepstra, A.; Van Den Berg, A.; Visser, L. The microenvironment of classical Hodgkin lymphoma: Heterogeneity by Epstein-Barr virus presence and location within the tumor. Blood Cancer J. 2016, 6. [CrossRef] [PubMed]

14. Gandhi, M.K.; Lambley, E.; Duraiswamy, J.; Dua, U.; Smith, C.; Elliott, S.; Gill, D.; Marlton, P.; Seymour, J.; Khanna, R. Expression of LAG-3 by tumor-infiltrating lymphocytes is coincident with the suppression of latent membrane antigen-Specific CD8 2 T-cell function in Hodgkin lymphoma patients. October 2006, 108, 2280-2289. [CrossRef]

15. Barros, M.H.M.; Vera-Lozada, G.; Soares, F.A.; Niedobitek, G.; Hassan, R. Tumor microenvironment composition in pediatric classical Hodgkin lymphoma is modulated by age and Epstein-Barr virus infection. Int. J. Cancer 2012, 131, 1142-1152. [CrossRef] [PubMed]

16. Teichmann, M.; Meyer, B.; Beck, A.; Niedobitek, G. Expression of the interferon-inducible chemokine IP-10 (CXCL10), a chemokine with proposed anti-neoplastic functions, in Hodgkin lymphoma and nasopharyngeal carcinoma. J. Pathol. 2005, 206, 68-75. [CrossRef] [PubMed]

17. Teruya-Feldstein, J.; Tosato, G.; Jaffe, E.S. The Role of Chemokines in Hodgkin's Disease. Leuk. Lymphoma 2000, 38, 363-371. [CrossRef] [PubMed]

18. Huang, Y.T.; Sheen, T.S.; Chen, C.L.; Lu, J.; Chang, Y.; Chen, J.Y.; Tsai, C.H. Profile of cytokine expression in nasopharyngeal carcinomas: A distinct expression of interleukin 1 in tumor and CD4+ T cells. Cancer Res. 1999, 59, 1599-1605. [PubMed]

19. Zong, Y.S.; Lin, H.; Choy, D.T.K.; Sham, J.S.T.; Wei, W.; Chan, K.H.; Ng, M.H. Nasopharyngeal Carcinoma and Lymphoinfiltration. Oncology 1991, 48, 290-296. [CrossRef] [PubMed]

20. Ferradini, L.; Miescher, S.; Stoeck, M.; Busson, P.; Barras, C.; Cerf-Bensussan, N.; Lipinski, M.; von Fliedner, V.; Tursz, T. Cytotoxic potential despite impaired activation pathways in T lymphocytes infiltrating nasopharyngeal carcinoma. Int. J. Cancer 1991, 47, 362-370. [CrossRef] [PubMed]

21. Zhang, Y.L.; Li, J.; Mo, H.Y.; Qiu, F.; Zheng, L.M.; Qian, C.N.; Zeng, Y.X. Different subsets of tumor infiltrating lymphocytes correlate with NPC progression in different ways. Mol. Cancer 2010, 9, 1-11. [CrossRef] [PubMed]

22. Hsin, L.-J.; Kao, H.-K.; Chen, I.-H.; Tsang, N.-M.; Hsu, C.-L.; Liu, S.-C.; Chang, Y.-S.; Chang, K.-P. Serum CXCL9 Levels Are Associated with Tumor Progression and Treatment Outcome in Patients with Nasopharyngeal Carcinoma. PLoS ONE 2013, 8, e80052. [CrossRef] [PubMed]

23. Tang, M.; Ou, N.; Li, C.; Lu, A.; Li, J.; Ma, L.; Zhong, W.; Gao, J.; Zheng, Y.; Cai, Y. Expression and Prognostic Significance of Macrophage Inflammatory Protein-3 Alpha and Cystatin A in Nasopharyngeal Carcinoma. Biomed Res. Int. 2015, 2015. [CrossRef] [PubMed]

24. Mrizak, D.; Martin, N.; Barjon, C.; Jimenez-Pailhes, A.-S.; Mustapha, R.; Niki, T.; Guigay, J.; Pancré, V.; de Launoit, Y.; Busson, P.; et al. Effect of Nasopharyngeal Carcinoma-Derived Exosomes on Human Regulatory T Cells. JNCI J. Natl. Cancer Inst. 2015, 107, 363. [CrossRef] [PubMed]

25. Beck, A.; Pazolt, D.; Grabenbauer, G.G.; Nicholls, J.M.; Herbst, H.; Young, L.S.; Niedobitek, G. Expression of cytokine and chemokine genes in Epstein-Barr virus- associated nasopharyngeal carcinoma: Comparison with Hodgkin's disease. J. Pathol. 2001, 194, 145-151. [CrossRef] [PubMed]

26. Haas, M.; Büttner, M.; Rau, T.T.; Fietkau, R.; Grabenbauer, G.G.; Distel, L.V. Inflammation in gastric adenocarcinoma of the cardia: How do EBV infection, Her2 amplification and cancer progression influence tumor-infiltrating lymphocytes? Virchows Arch. 2011, 458, 403-411. [CrossRef] [PubMed]

27. Feichtenbeiner, A.; Haas, M.; Büttner, M.; Grabenbauer, G.G.; Fietkau, R.; Distel, L.V. Critical role of spatial interaction between CD8+ and Foxp3 + cells in human gastric cancer: The distance matters. Cancer Immunol. Immunother. 2014, 63, 111-119. [CrossRef] [PubMed]

28. Kijima, Y.; Ishigami, S.; Hokita, S.; Koriyama, C.; Akiba, S.; Eizuru, Y.; Aikou, T. The comparison of the prognosis between Epstein-Barr virus (EBV)-positive gastric carcinomas and EBV-negative ones. Cancer Lett. 2003, 200, 33-40. [CrossRef]

29. Chiaravalli, A.M.; Feltri, M.; Bertolini, V.; Bagnoli, E.; Furlan, D.; Cerutti, R.; Novario, R.; Capella, C. Intratumour $\mathrm{T}$ cells, their activation status and survival in gastric carcinomas characterised for microsatellite instability and Epstein-Barr virus infection. Virchows Arch. 2006, 448, 344-353. [CrossRef] [PubMed] 
30. Ma, J.; Li, J.; Hao, Y.; Nie, Y.; Li, Z.; Qian, M.; Liang, Q.; Yu, J.; Zeng, M.; Wu, K. Differentiated tumor immune microenvironment of Epstein-Barr virus-associated and negative gastric cancer: Implication in prognosis and immunotherapy. Oncotarget 2017, 8, 67094-67103. [CrossRef] [PubMed]

31. Zhang, N.; Chen, J.; Xiao, L.; Tang, F.; Zhang, Z.; Zhang, Y.; Feng, Z.; Jiang, Y.; Shao, C. Accumulation Mechanisms of CD4(+)CD25(+)FOXP3(+) Regulatory T Cells in EBV-associated Gastric Carcinoma. Sci. Rep. 2015, 5, 18057. [CrossRef] [PubMed]

32. Strong, M.J.; Xu, G.; Coco, J.; Baribault, C.; Vinay, D.S.; Lacey, M.R.; Strong, A.L.; Lehman, T.A.; Seddon, M.B.; Lin, Z.; et al. Differences in Gastric Carcinoma Microenvironment Stratify According to EBV Infection Intensity: Implications for Possible Immune Adjuvant Therapy. PLoS Pathog. 2013, 9. [CrossRef] [PubMed]

33. Ohtani, H.; Nakayama, T.; Yoshie, O. In situ expression of the CCL20-CCR6 axis in lymphocyte-rich gastric cancer and its potential role in the formation of lymphoid stroma. Pathol. Int. 2011, 645-651. [CrossRef] [PubMed]

34. Lu, J.; Chen, X.-M.; Huang, H.-R.; Zhao, F.-P.; Wang, F.; Liu, X.; Li, X.-P. Detailed analysis of inflammatory cell infiltration and the prognostic impact on nasopharyngeal carcinoma. Head Neck 2018. [CrossRef] [PubMed]

35. Miao, B.P.; Zhang, R.S.; Li, M.; Fu, Y.T.; Zhao, M.; Liu, Z.G.; Yang, P.C. Nasopharyngeal cancer-derived microRNA-21 promotes immune suppressive B cells. Cell. Mol. Immunol. 2015, 12, 750-756. [CrossRef] [PubMed]

36. Agathanggelou, A.; Niedobitek, G.; Chen, R.; Nicholls, J.; Yin, W.; Young, L.S. Expression of immune regulatory molecules in Epstein-Barr virus-associated nasopharyngeal carcinomas with prominent lymphoid stroma. Evidence for a functional interaction between epithelial tumor cells and infiltrating lymphoid cells. Am. J. Pathol. 1995, 147, 1152-1160. [PubMed]

37. Braz-Silva, P.H.; Vitale, S.; Butori, C.; Guevara, N.; Santini, J.; Magalhães, M.; Hofman, P.; Doglio, A. Specific infiltration of langerin-positive dendritic cells in EBV-infected tonsil, Hodgkin lymphoma and nasopharyngeal carcinoma. Int. J. Cancer 2011, 128, 2501-2508. [CrossRef] [PubMed]

38. Zong, Y.; Zhang, C.; Zhang, F.; Kuan, J.; Chen, M.; Feng, K.; Yu, Z. Infiltrating Lymphocytes and Accessory Cells in Nasopharyngeal Carcinoma 1. Jpn. J. Cancer Res. 1993, 84, 900-905. [CrossRef] [PubMed]

39. Giannini, A.; Bianchi, S.; Messerini, L.; Gallo, O.; Gallina, E.; Asprella Libonati, G.; Olmi, P.; Zampi, G. Prognostic Significance of Accessory Cells and Lymphocytes in Nasopharyngeal Carcinoma. Pathol. Res. Pract. 1991, 187, 496-502. [CrossRef]

40. Chapel, F.; Fabiani, B.; Davi, F.; Raphael, M.; Tepper, M.; Champault, G.; Guettier, C. Epstein-Barr virus and gastric carcinoma in Western patients: Comparison of pathological parameters and p53 expression in EBV-positive and negative tumours. Histopathology 2000, 36, 252-261. [CrossRef] [PubMed]

41. Lo, M.C.; Yip, T.C.; Ngan, K.C.; Cheng, W.W.; Law, C.K.; Chan, P.S.; Chan, K.C.; Wong, C.K.C.; Wong, R.N.S.; Lo, K.W.; et al. Role of MIF/CXCL8/CXCR2 signaling in the growth of nasopharyngeal carcinoma tumor spheres. Cancer Lett. 2013, 335, 81-92. [CrossRef] [PubMed]

42. Tang, K.F.; Tan, S.Y.; Chan, S.H.; Chong, S.M.; Loh, K.S.; Tan, L.K.S.; Hu, H. A distinct expression of CC chemokines by macrophages in nasopharyngeal carcinoma: Implication for the intense tumor infiltration by T lymphocytes and macrophages. Hum. Pathol. 2001, 32, 42-49. [CrossRef] [PubMed]

43. Hollander, P.; Rostgaard, K.; Smedby, K.E.; Molin, D.; Loskog, A.; de Nully Brown, P.; Enblad, G.; Amini, R.M.; Hjalgrim, H.; Glimelius, I. An anergic immune signature in the tumor microenvironment of classical Hodgkin lymphoma is associated with inferior outcome. Eur. J. Haematol. 2017, 88-97. [CrossRef] [PubMed]

44. Zameer, M.A.L.; Premalata, C.S.; Arunakumari, B.; Appaji, L.; Rama Rao, C. Pediatric hodgkin lymphoma in a south indian regional cancer center: Its immunomorphology, tumor-Associated macrophages, and association with epstein-barr virus. Pediatr. Hematol. Oncol. 2015, 32, 229-238. [CrossRef] [PubMed]

45. Kamper, P.; Bendix, K.; Hamilton-Dutoit, S.; Honore, B.; Nyengaard, J.R.; D'Amore, F. Tumor-infiltrating macrophages correlate with adverse prognosis and Epstein-Barr virus status in classical Hodgkin's lymphoma. Haematologica 2011, 96, 269-276. [CrossRef] [PubMed]

46. Barros, M.H.M.; Hassan, R.; Niedobitek, G. Tumor-associated macrophages in pediatric classical Hodgkin lymphoma: Association with Epstein-Barr virus, lymphocyte subsets, and prognostic impact. Clin. Cancer Res. 2012, 18, 3762-3771. [CrossRef] [PubMed]

47. Barros, M.H.M.; Segges, P.; Vera-Lozada, G.; Hassan, R.; Niedobitek, G. Macrophage polarization reflects T cell composition of tumor microenvironment in pediatric classical Hodgkin lymphoma and has impact on survival. PLoS ONE 2015, 10, 1-19. [CrossRef] [PubMed] 
48. Ooft, M.L.; van Ipenburg, J.A.; Sanders, M.E.; Kranendonk, M.; Hofland, I.; de Bree, R.; Koljenović, S.; Willems, S.M. Prognostic role of tumour-associated macrophages and regulatory T cells in EBV-positive and EBV-negative nasopharyngeal carcinoma. J. Clin. Pathol. 2017. [CrossRef] [PubMed]

49. Peng, J.; Ding, T.; Zheng, L.-M.; Shao, J.-Y. Influence of tumor-associated macrophages on progression and prognosis of nasopharyngeal carcinoma. Ai Zheng 2006, 25, 1340-1345. [PubMed]

50. Huang, H.; Liu, X.; Zhao, F.; Lu, J.; Zhang, B.; Peng, X.; Zhang, M.; Chen, X.; Li, G.; Li, X. M2-polarized tumour-associated macrophages in stroma correlate with poor prognosis and Epstein-Barr viral infection in nasopharyngeal carcinoma. Acta Otolaryngol. 2017, 137, 888-894. [CrossRef] [PubMed]

51. Buettner, M.; Meyer, B.; Schreck, S.; Niedobitek, G. Expression of RANTES and MCP-1 in epithelial cells is regulatedvia LMP1 and CD40. Int. J. Cancer 2007, 121, 2703-2710. [CrossRef] [PubMed]

52. Ichimura, T.; Abe, H.; Morikawa, T.; Yamashita, H.; Ishikawa, S.; Ushiku, T.; Seto, Y.; Fukayama, M. Low density of CD204-positive M2-type tumor-associated macrophages in Epstein-Barr virus-associated gastric cancer: A clinicopathologic study with digital image analysis. Hum. Pathol. 2016, 56, 74-80. [CrossRef] [PubMed]

53. Marini, O.; Spina, C.; Mimiola, E.; Cassaro, A.; Malerba, G.; Todeschini, G.; Perbellini, O.; Scupoli, M.; Carli, G.; Facchinelli, D.; et al. Identification of granulocytic myeloid-derived suppressor cells (G-MDSCs) in the peripheral blood of Hodgkin and non-Hodgkin lymphoma patients. Oncotarget 2016, 7, 27676-27688. [CrossRef] [PubMed]

54. Romano, A.; Parrinello, N.L.; Vetro, C.; Forte, S.; Chiarenza, A.; Figuera, A.; Motta, G.; Palumbo, G.A.; Ippolito, M.; Consoli, U.; et al. Di Circulating myeloid-derived suppressor cells correlate with clinical outcome in Hodgkin Lymphoma patients treated up-front with a risk-adapted strategy. Br. J. Haematol. 2015, 168, 689-700. [CrossRef] [PubMed]

55. Li, Z.-L.; Ye, S.-B.; OuYang, L.-Y.; Zhang, H.; Chen, Y.-S.; He, J.; Chen, Q.-Y.; Qian, C.-N.; Zhang, X.-S.; Cui, J.; et al. COX-2 promotes metastasis in nasopharyngeal carcinoma by mediating interactions between cancer cells and myeloid-derived suppressor cells. Oncoimmunology 2015, 4, e1044712. [CrossRef] [PubMed]

56. Dai, X.C.; Liu, L.Q.; Wang, B.H.; Wang, C.M.; Ma, L.; Cao, W.M.; Dai, E.X. Effect of concurrent chemoradiotherapy and radiotherapy alone on peripheral myeloid-derived suppressor and T regulatory cells in patients with nasopharyngeal cancer. Zhonghua Zhong Liu Za Zhi 2017, 39, 579-583. [PubMed]

57. Gabitass, R.F.; Annels, N.E.; Stocken, D.D.; Pandha, H.A.; Middleton, G.W. Elevated myeloid-derived suppressor cells in pancreatic, esophageal and gastric cancer are an independent prognostic factor and are associated with significant elevation of the Th2 cytokine interleukin-13. Cancer Immunol. Immunother. 2011, 60, 1419-1430. [CrossRef] [PubMed]

58. Shoji, H.; Tada, K.; Kitano, S.; Nishimura, T.; Shimada, Y.; Nagashima, K.; Aoki, K.; Hiraoka, N.; Honma, Y.; Iwasa, S.; et al. The peripheral immune status of granulocytic myeloid-derived suppressor cells correlates the survival in advanced gastric cancer patients receiving cisplatin-based chemotherapy. Oncotarget 2017, 8, 95083-95094. [CrossRef] [PubMed]

59. Wang, L.; Chang, E.W.Y.; Wong, S.C.; Ong, S.-M.; Chong, D.Q.Y.; Ling, K.L. Increased Myeloid-Derived Suppressor Cells in Gastric Cancer Correlate with Cancer Stage and Plasma S100A8/ A9 Proinflammatory Proteins. J. Immunol. 2013, 190, 794-804. [CrossRef] [PubMed]

60. Choi, H.S.; Ha, S.Y.; Kim, H.-M.; Ahn, S.M.; Kang, M.-S.; Kim, K.-M.; Choi, M.G.; Lee, J.H.; Sohn, T.S.; Bae, J.M.; et al. The prognostic effects of tumor infiltrating regulatory $\mathrm{T}$ cells and myeloid derived suppressor cells assessed by multicolor flow cytometry in gastric cancer patients. Oncotarget 2016, 7, 7940-7951. [CrossRef] [PubMed]

61. Dong, J.; Li, J.; Liu, S.-M.; Feng, X.-Y.; Chen, S.; Chen, Y.-B.; Zhang, X.-S. CD33+/p-STAT1+ double-positive cell as a prognostic factor for stage IIIa gastric cancer. Med. Oncol. 2013, 30, 442. [CrossRef] [PubMed]

62. Cai, T.T.; Ye, S.B.; Liu, Y.N.; He, J.; Chen, Q.Y.; Mai, H.Q.; Zhang, C.X.; Cui, J.; Zhang, X.S.; Busson, P.; et al. LMP1-mediated glycolysis induces myeloid-derived suppressor cell expansion in nasopharyngeal carcinoma. PLoS Pathog. 2017, 13, 1-23. [CrossRef] [PubMed]

63. Chen, L.C.; Wang, L.J.; Tsang, N.M.; Ojcius, D.M.; Chen, C.C.; Ouyang, C.N.; Hsueh, C.; Liang, Y.; Chang, K.P.; Chen, C.C.; et al. Tumour inflammasome-derived IL-1 $\beta$ recruits neutrophils and improves local recurrence-free survival in EBV-induced nasopharyngeal carcinoma. EMBO Mol. Med. 2012, 4, 1276-1293. [CrossRef] [PubMed] 
64. Abe, H.; Morikawa, T.; Saito, R.; Yamashita, H.; Seto, Y.; Fukayama, M. In Epstein-Barr virus-associated gastric carcinoma a high density of CD66b-positive tumor-associated neutrophils is associated with intestinal-type histology and low frequency of lymph node metastasis. Virchows Arch. 2016, 468, 539-548. [CrossRef] [PubMed]

65. Samoszuk, M. Invited Revie w Eosinophils and human cancer. Histol. Histopathol. 1987, 12, 807-881.

66. Glimelius, I.; Rubin, J.; Rostgaard, K.; Amini, R.M.; Simonsson, M.; Sorensen, K.M.; Smedby, K.E.; Venge, P.; Hjalgrim, H.; Molin, D.; et al. Predictors of histology, tissue eosinophilia and mast cell infiltration in Hodgkin's Lymphoma-A population-based study. Eur. J. Haematol. 2011, 87, 208-216. [CrossRef] [PubMed]

67. Von Wasielewski, R.; Seth, S.; Franklin, J.; Fischer, R.; Hübner, K.; Hansmann, M.L.; Diehl, V.; Georgii, A. Tissue eosinophilia correlates strongly with poor prognosis in nodular sclerosing Hodgkin's disease, allowing for known prognostic factors. Blood 2000, 95, 1207-1213. [PubMed]

68. Looi, L.-M. Tumor-associated tissue eosinophilia in nasopharyngeal carcinoma. A pathologic study of 422 primary and 138 metastatic tumors. Cancer 1987, 59, 466-470. [CrossRef]

69. Liu, C.M.; Ko, J.J.; Shun, C.T.; Hsiao, T.Y.; Sheen, T.S. Soluble adhesion molecules and cytokines in tumor-associated tissue eosinophilia of nasopharyngeal carcinoma. Acta Otolaryngol. 2001, 121, 534-538. [CrossRef] [PubMed]

70. Fujii, M.; Yamashita, T.; Ishiguro, R.; Tashiro, M. Significance of epidermal growth factor receptor and tumor associated tissue eosinophilia in the prognosis of patients with nasopharyngeal carcinoma. Auris Nasus Larynx 2002, 29, 175-181. [CrossRef]

71. Caruso, R.A.; Parisi, A.; Quattrocchi, E.; Scardigno, M.; Branca, G.; Parisi, C.; Lucianò, R.; Paparo, D.; Fedele, F. Ultrastructural descriptions of heterotypic aggregation between eosinophils and tumor cells in human gastric carcinomas. Ultrastruct. Pathol. 2011, 35, 145-149. [CrossRef] [PubMed]

72. Andersen, M.D.; Kamper, P.; Nielsen, P.S.; Bendix, K.; Riber-Hansen, R.; Steiniche, T.; Hamilton-Dutoit, S.; Clausen, M.; d'Amore, F. Tumour-associated mast cells in classical Hodgkin's lymphoma: Correlation with histological subtype, other tumour-infiltrating inflammatory cell subsets and outcome. Eur. J. Haematol. 2016, 96, 252-259. [CrossRef] [PubMed]

73. Molin, D.; Edstrom, A.; Glimelius, I.; Glimelius, B.; Nilsson, G.; Sundstrom, C.; Enblad, G. Mast cell infiltration correlates with poor prognosis in Hodgkin's lymphoma. Br. J. Haematol. 2002, 119, 122-124. [CrossRef] [PubMed]

74. Hügle, T. Beyond allergy: The role of mast cells in fibrosis. Swiss Med. Wkly. 2014, 144, 1-8. [CrossRef] [PubMed]

75. Chen, X.; Li, X.; Zhao, F.; Huang, H.; Lu, J.; Liu, X. Distribution and prognostic significance of tumorinfiltrating mast cells in nasopharyngeal carcinoma. Zhonghua Er Bi Yan Hou Tou Jing Wai Ke Za Zhi 2015, 50, 306-311. [PubMed]

76. Ribatti, D.; Guidolin, D.; Marzullo, A.; Nico, B.; Annese, T.; Benagiano, V.; Crivellato, E. Mast cells and angiogenesis in gastric carcinoma. Int. J. Exp. Pathol. 2010, 91, 350-356. [CrossRef] [PubMed]

77. Ammendola, M.; Sacco, R.; Zuccalà, V.; Luposella, M.; Patruno, R.; Gadaleta, P.; Zizzo, N.; Gadaleta, C.D.; De Sarro, G.; Sammarco, G.; et al. Mast cells density positive to tryptase correlate with microvascular density in both primary gastric cancer tissue and loco-regional lymph node metastases from patients that have undergone radical surgery. Int. J. Mol. Sci. 2016, 17, 1-11. [CrossRef] [PubMed]

78. Wang, S.; Ma, N.; Kawanishi, S.; Hiraku, Y.; Oikawa, S.; Xie, Y.; Zhang, Z.; Huang, G.; Murata, M. Relationships of alpha-SMA-positive fibroblasts and SDF-1-positive tumor cells with neoangiogenesis in nasopharyngeal carcinoma. Biomed Res. Int. 2014, 2014. [CrossRef] [PubMed]

79. Chen, J.; Yang, P.; Xiao, Y.; Zhang, Y.; Liu, J.; Xie, D.; Cai, M.; Zhang, X. Overexpression of $\alpha$-sma-positive fibroblasts (CAFs) in Nasopharyngeal Carcinoma Predicts Poor Prognosis. J. Cancer 2017, 8, 3897-3902. [CrossRef] [PubMed]

80. Wang, R.F.; Zhang, L.H.; Shan, L.H.; Sun, W.G.; Chai, C.C.; Wu, H.M.; Ibla, J.C.; Wang, L.F.; Liu, J.R. Effects of the fibroblast activation protein on the invasion and migration of gastric cancer. Exp. Mol. Pathol. 2013, 95, 350-356. [CrossRef] [PubMed]

81. Mueller, M.M.; Fusenig, N.E. Friends or foes - Bipolar effects of the tumour stroma in cancer. Nat. Rev. Cancer 2004, 4, 839-849. [CrossRef] [PubMed]

82. Kalluri, R.; Zeisberg, M. Fibroblasts in cancer. Nat. Rev. Cancer 2006, 6, 392-401. [CrossRef] [PubMed]

83. Michiels, C. Endothelial cell functions. J. Cell. Physiol. 2003, 196, 430-443. [CrossRef] [PubMed] 
84. Doussis-Anagnostopoulou, I.A.; Talks, K.L.; Turley, H.; Debnam, P.; Tan, D.C.; Mariatos, G.; Gorgoulis, V.; Kittas, C.; Gatter, K.C. Vascular endothelial growth factor (VEGF) is expressed by neoplastic HodgkinReed-Sternberg cells in Hodgkin's disease. J. Pathol. 2002, 197, 677-683. [CrossRef] [PubMed]

85. Murono, S.; Inoue, H.; Tanabe, T.; Joab, I.; Yoshizaki, T.; Furukawa, M.; Pagano, J.S. Induction of cyclooxygenase-2 by Epstein-Barr virus latent membrane protein 1 is involved in vascular endothelial growth factor production in nasopharyngeal carcinoma cells. Proc. Natl. Acad. Sci. USA 2001, 98, 6905-6910. [CrossRef] [PubMed]

86. Fhu, C.W.; Graham, A.M.; Yap, C.T.; Al-Salam, S.; Castella, A.; Chong, S.M.; Lim, Y.C. Reed-Sternberg cell-derived lymphotoxin-alpha activates endothelial cells to enhance T-cell recruitment in classical Hodgkin lymphoma. Blood 2014, 124, 2973-2982. [CrossRef] [PubMed]

87. Zhao, Y.; Wang, Y.; Zeng, S.; Hu, X. LMP1 expression is positively associated with metastasis of nasopharyngeal carcinoma: Evidence from a meta-analysis. J. Clin. Pathol. 2012, 65, 41-45. [CrossRef] [PubMed]

88. Ribeiro, J.; Oliveira, C.; Sousa, H. Epstein-Barr virus gene expression and latency pattern in gastric carcinomas: A systematic review. Future Oncol. 2017, 13, 567-579. [CrossRef] [PubMed]

89. Seto, E.; Yang, L.; Middeldorp, J.; Sheen, T.S.; Chen, J.Y.; Fukayama, M.; Eizuru, Y.; Ooka, T.; Takada, K. Epstein-Barr virus (EBV)-encoded BARF1 gene is expressed in nasopharyngeal carcinoma and EBV-associated gastric carcinoma tissues in the absence of lytic gene expression. J. Med. Virol. 2005, 76, 82-88. [CrossRef] [PubMed]

90. Brink, A.A.T.P.; Vervoort, M.B.H.J.; Middeldorp, J.M.; Meijer, C.J.L.M.; Van Den Brule, A.J.C. Nucleic acid sequence-based amplification, a new method for analysis of spliced and unspliced Epstein-Barr virus latent transcripts, and its comparison with reverse transcriptase PCR. J. Clin. Microbiol. 1998, 36, 3164-3169. [PubMed]

91. Blake, N.; Lee, S.; Redchenko, I.; Thomas, W.; Steven, N.; Leese, A.; Steigerwald-Mullen, P.; Kurilla, M.G.; Frappier, L.; Rickinson, A. Human CD8+T cell responses to EBV EBNA1: HLA class I presentation of the (Gly-Ala)-containing protein requires exogenous processing. Immunity 1997, 7, 791-802. [CrossRef]

92. Jones, K.; Nourse, J.P.; Morrison, L.; Nguyen-Van, D.; Moss, D.J.; Burrows, S.R.; Gandhi, M.K. Expansion of EBNA1-specific effector T cells in posttransplantation lymphoproliferative disorders. Blood 2010, 116, 2245-2252. [CrossRef] [PubMed]

93. Long, H.M.; Chagoury, O.L.; Leese, A.M.; Ryan, G.B.; James, E.; Morton, L.T.; Abbott, R.J.M.; Sabbah, S.; Kwok, W.; Rickinson, A.B. MHC II tetramers visualize human CD4 ${ }^{+} \mathrm{T}$ cell responses to Epstein-Barr virus infection and demonstrate atypical kinetics of the nuclear antigen EBNA1 response. J. Exp. Med. 2013, 210, 933-949. [CrossRef] [PubMed]

94. Lin, X.; Gudgeon, N.H.; Hui, E.P.; Jia, H.; Qun, X.; Taylor, G.S.; Barnardo, M.C.N.M.; Lin, C.K.; Rickinson, A.B.; Chan, A.T.C. CD4 and CD8 T cell responses to tumour-associated Epstein-Barr virus antigens in nasopharyngeal carcinoma patients. Cancer Immunol. Immunother. 2008, 57, 963-975. [CrossRef] [PubMed]

95. Nijland, M.; Veenstra, R.N.; Visser, L.; Xu, C.; Kushekhar, K.; van Imhoff, G.W.; Kluin, P.M.; van den Berg, A.; Diepstra, A. HLA dependent immune escape mechanisms in B-cell lymphomas: Implications for immune checkpoint inhibitor therapy? Oncoimmunology 2017, 6, 1-8. [CrossRef] [PubMed]

96. Rowe, M.; Khanna, R.; Jacob, C.A.; Argaet, V.; Kelly, A.; Powis, S.; Belich, M.; Groom-Carter, D.; Lee, S.; Burrows, S.R.; et al. Restoration of endogenous antigen processing in Burkitt's lymphoma cells by Epstein-Barr virus latent membrane protein-1: Coordinate up-regulation of peptide transporters and HLA-class I antigen expression. Eur. J. Immunol. 1995, 25, 1374-1384. [CrossRef] [PubMed]

97. Liu, Y.; van den Berg, A.; Veenstra, R.; Rutgers, B.; Nolte, I.; van Imhoff, G.; Visser, L.; Diepstra, A. PML Nuclear Bodies and SATB1 Are Associated with HLA Class I Expression in EBV+ Hodgkin Lymphoma. PLoS ONE 2013, 8. [CrossRef] [PubMed]

98. Ogino, T.; Moriai, S.; Ishida, Y.; Ishii, H.; Katayama, A.; Miyokawa, N.; Harabuchi, Y.; Ferrone, S. Association of immunoescape mechanisms with Epstein-Barr virus infection in nasopharyngeal carcinoma. Int. J. Cancer 2007, 120, 2401-2410. [CrossRef] [PubMed] 
99. Ren, Y.-X.; Yang, J.; Zhang, L.-J.; Sun, R.-M.; Zhao, L.-F.; Zhang, M.; Chen, Y.; Ma, J.; Qiao, K.; Sun, Q.-M.; et al. Downregulation of expression of transporters associated with antigen processing 1 and 2 and human leukocyte antigen I and its effect on immunity in nasopharyngeal carcinoma patients. Mol. Clin. Oncol. 2014, 2, 51-58. [CrossRef] [PubMed]

100. Chen, B.J.; Chapuy, B.; Ouyang, J.; Sun, H.H.; Roemer, M.G.M.; Xu, M.L.; Yu, H.; Fletcher, C.D.M.; Freeman, G.J.; Shipp, M.A.; et al. PD-L1 expression is characteristic of a subset of aggressive B-cell lymphomas and virus-associated malignancies. Clin. Cancer Res. 2013, 19, 3462-3473. [CrossRef] [PubMed]

101. Derks, S.; Liao, X.; Chiaravalli, A.M.; Xu, X.; Camargo, M.C.; Solcia, E.; Sessa, F.; Fleitas, T.; Freeman, G.J.; Rodig, S.J.; et al. Abundant PD-L1 expression in Epstein-Barr Virus-infected gastric cancers. Oncotarget 2016, 7, 32925-32932. [CrossRef] [PubMed]

102. Saito, R.; Abe, H.; Kunita, A.; Yamashita, H.; Seto, Y.; Fukayama, M. Overexpression and gene amplification of PD-L1 in cancer cells and PD-L1 + immune cells in Epstein-Barr virus-associated gastric cancer: The prognostic implications. Mod. Pathol. 2017, 30, 427-439. [CrossRef] [PubMed]

103. Fang, W.; Zhang, J.; Hong, S.; Zhan, J.; Chen, N.; Qin, T.; Tang, Y.; Zhang, Y.; Kang, S.; Zhou, T.; et al. EBV-driven LMP1 and IFN- $\gamma$ up-regulate PD-L1 in nasopharyngeal carcinoma: Implications for oncotargeted therapy. Oncotarget 2014, 5, 12189-12202. [CrossRef] [PubMed]

104. Green, M.R.; Rodig, S.; Juszczynski, P.; Ouyang, J.; Sinha, P.; O’Donnell, E.; Neuberg, D.; Shipp, M.A. Constitutive AP-1 Activity and EBV Infection Induce PD-L1 in Hodgkin Lymphomas and Posttransplant Lymphoproliferative Disorders: Implications for Targeted Therapy. Clin. Cancer Res. 2012, 18, 1611-1618. [CrossRef] [PubMed]

105. Cancer Genome Atlas Research Network. Comprehensive molecular characterization of gastric adenocarcinoma. Nature 2014, 513, 202-209. [CrossRef]

106. Huang, P.-Y.; Guo, S.-S.; Zhang, Y.; Lu, J.-B.; Chen, Q.-Y.; Tang, L.-Q.; Zhang, L.; Liu, L.-T.; Zhang, L.; Mai, H.-Q. Tumor CTLA-4 overexpression predicts poor survival in patients with nasopharyngeal carcinoma. Oncotarget 2016, 7, 13060-13068. [CrossRef] [PubMed]

107. Herling, M.; Rassidakis, G.Z.; Medeiros, L.J.; Vassilakopoulos, T.P.; Kliche, K.; Nadali, G.; Viviani, S.; Bonfante, V.; Giardini, R.; Chilosi, M.; et al. Expression of Epstein-Barr Virus Latent Membrane Protein-1 in Hodgkin and Reed-Sternberg Cells of Classical Hodgkin â€ ${ }^{\mathrm{TM}} \mathrm{s}$ Lymphoma: Associations with Presenting Features, Serum Interleukin 10 Levels, and Clinical Outcome Expression of Epstein-Barr Virus. Afr. Health Sci. 2003, 9, 2114-2120.

108. Ohshima, K.; Suzumiya, J.; Akamatu, M.; Takeshjta, M.; Kikuchi, M. Human and viral interleukin-10 in Hodgkin's disease, and its influence on CD4+ and CD8+ T lymphocytes. Int. J. Cancer 1995, 62, 5-10. [CrossRef] [PubMed]

109. Yao, M.; Ohshima, K.; Suzumiya, J.; Kume, T.; Shiroshita, T.O.; Kikuchi, M. Interleukin-10 expression and cytotoxic-T-cell response in Epstein-Barr-virus-associated nasopharyngeal carcinoma. Int. J. Cancer 1997, 72, 398-402. [CrossRef]

110. Pachnia, D.; Drop, B.; Dworzańska, A.; Kliszczewska, E.; Polz-Dacewicz, M. Transforming Growth Factor- $\beta$, Interleukin-10, and Serological Markers in EBV-associated Gastric Carcinoma. Anticancer Res. 2017, 37, 4853-4858. [CrossRef] [PubMed]

111. Sakamoto, T.; Saito, H.; Tatebe, S.; Tsujitani, S.; Ozaki, M.; Ito, H.; Ikeguchi, M. Interleukin-10 expression significantly correlates with minor CD8 + T-cell infiltration and high microvessel density in patients with gastric cancer. Int. J. Cancer 2006, 118, 1909-1914. [CrossRef] [PubMed]

112. Incrocci, R.; Barse, L.; Stone, A.; Vagvala, S.; Montesano, M.; Subramaniam, V.; Swanson-Mungerson, M. Epstein-Barr Virus Latent Membrane Protein 2A (LMP2A) enhances IL-10 production through the activation of Bruton's tyrosine kinase and STAT3. Virology 2017, 500, 96-102. [CrossRef] [PubMed]

113. Chao, P.-Z.; Hsieh, M.-S.; Cheng, C.-W.; Hsu, T.-J.; Lin, Y.-T.; Lai, C.-H.; Liao, C.-C.; Chen, W.-Y.; Leung, T.-K.; Lee, F.-P.; et al. Dendritic cells respond to nasopharygeal carcinoma cells through annexin A2-recognizing DC-SIGN. Oncotarget 2015, 6, 159-170. [CrossRef] [PubMed]

114. Fridlender, Z.G.; Sun, J.; Kim, S.; Kapoor, V.; Cheng, G.; Ling, L.; Worthen, G.S.; Albelda, S.M. Polarization of Tumor-Associated Neutrophil Phenotype by TGF- $\beta$ : “N1” versus “N2” TAN. Cancer Cell 2009, 16, 183-194. [CrossRef] [PubMed] 
115. Maggio, E.; van den Berg, A.; Diepstra, A.; Kluiver, J.; Visser, L.; Poppema, S. Chemokines, cytokines and their receptors in Hodgkin's lymphoma cell lines and tissues. Ann. Oncol. Off. J. Eur. Soc. Med. Oncol. 2002, 13 (Suppl 1), 52-56. [CrossRef]

116. Umansky, V.; Blattner, C.; Gebhardt, C.; Utikal, J. The Role of Myeloid-Derived Suppressor Cells (MDSC) in Cancer Progression. Vaccines 2016, 4, 36. [CrossRef] [PubMed]

117. Tang, C.-E.; Tan, T.; Li, C.; Chen, Z.-C.; Ruan, L.; Wang, H.-H.; Su, T.; Zhang, P.-F.; Xiao, Z.-Q. Identification of Galectin-1 as a novel biomarker in nasopharyngeal carcinoma by proteomic analysis. Oncol. Rep. 2010, 24, 495-500. [CrossRef] [PubMed]

118. Gandhi, M.K.; Moll, G.; Smith, C.; Dua, U.; Lambley, E.; Ramuz, O.; Gill, D.; Marlton, P.; Seymour, J.F.; Khanna, R. Brief report Galectin-1 mediated suppression of Epstein-Barr virus-Specific T-cell immunity in classic Hodgkin lymphoma. Boold 2015, 110, 1326-1330. [CrossRef]

119. Klibi, J.; Niki, T.; Riedel, A.; Pioche-durieu, C.; Souquere, S.; Rubinstein, E.; Moulec, S.L.; Hirashima, M.; Guemira, F.; Adhikary, D.; et al. Blood diffusion and Th1-suppressive effects of galectin-9—Containing exosomes released by Epstein-Barr virus-Infected nasopharyngeal carcinoma cells. Blood 2009, 113, 1957-1966. [CrossRef] [PubMed]

120. Diepstra, A.; Van Imhoff, G.W.; Schaapveld, M.; Karim-Kos, H.; Van Den Berg, A.; Vellenga, E.; Poppema, S. Latent Epstein-Barr virus infection of tumor cells in classical Hodgkin's lymphoma predicts adverse outcome in older adult patients. J. Clin. Oncol. 2009, 27, 3815-3821. [CrossRef] [PubMed]

121. Cai, M.B.; Han, H.Q.; Bei, J.X.; Liu, C.C.; Lei, J.J.; Cui, Q.; Feng, Q.S.; Wang, H.Y.; Zhang, J.X.; Liang, Y.; et al. Expression of human leukocyte antigen $\mathrm{G}$ is associated with prognosis in nasopharyngeal carcinoma. Int. J. Biol. Sci. 2012, 8, 891-900. [CrossRef] [PubMed]

122. Chiu, J.; Ernst, D.M.; Keating, A. Acquired natural killer cell dysfunction in the tumor microenvironment of classic Hodgkin lymphoma. Front. Immunol. 2018, 9, 1-9. [CrossRef] [PubMed]

123. Krappmann, D.; Emmerich, F.; Kordes, U.; Scharschmidt, E.; Do, B.; Scheidereit, C. Molecular mechanisms of constitutive NF-kB/Rel activation in Hodgkin. Oncogene 1999, 18, 943. [CrossRef] [PubMed]

124. Cabannes, E.; Khan, G.; Aillet, F.; Jarrett, R.F.; Hay, R.T. Mutations in the IkBa gene in Hodgkin's disease suggest a tumour suppressor role for IKB $\alpha$. Oncogene 1999, 18, 3063-3070. [CrossRef] [PubMed]

125. Joos, S.; Menz, C.K.; Wrobel, G.; Siebert, R.; Gesk, S.; Ohl, S.; Mechtersheimer, G.; Trümper, L.; Moller, P.; Lichter, P.; et al. Classical Hodgkin lymphoma is characterized by recurrent copy number gains of the short arm of chromosome 2. Blood 2002, 99, 1381-1387. [CrossRef] [PubMed]

126. Nomoto, J.; Hiramoto, N.; Kato, M.; Sanada, M.; Maeshima, A.M.; Taniguchi, H.; Hosoda, F.; Asakura, Y.; Munakata, W.; Sekiguchi, N.; et al. Deletion of the TNFAIP3/A20gene detected by FICTION analysis in classical Hodgkin lymphoma. BMC Cancer 2012, 12, 457. [CrossRef] [PubMed]

127. Chung, G.T.Y.; Lou, W.P.K.; Chow, C.; To, K.F.; Choy, K.W.; Leung, A.W.C.; Tong, C.Y.K.; Yuen, J.W.F.; Ko, C.W.; Yip, T.T.C.; et al. Constitutive activation of distinct NF- $\mathrm{kB}$ signals in EBV-associated nasopharyngeal carcinoma. J. Pathol. 2013, 231, 311-322. [CrossRef] [PubMed]

128. Chow, Y.P.; Tan, L.P.; Chai, S.J.; Abdul Aziz, N.; Choo, S.W.; Lim, P.V.H.; Pathmanathan, R.; Kornain, N.K.M.; Lum, C.L.; Pua, K.C.; et al. Exome Sequencing Identifies Potentially Druggable Mutations in Nasopharyngeal Carcinoma. Sci. Rep. 2017, 7, 1-14. [CrossRef] [PubMed]

129. Heussinger, N.; Büttner, M.; Ott, G.; Brachtel, E.; Pilch, B.Z.; Kremmer, E.; Niedobitek, G. Expression of the Epstein-Barr virus (EBV)-encoded latent membrane protein 2A (LMP2A) in EBV-associated nasopharyngeal carcinoma. J. Pathol. 2004, 203, 696-699. [CrossRef] [PubMed]

130. Kong, Q.L.; Hu, L.J.; Cao, J.Y.; Huang, Y.J.; Xu, L.H.; Liang, Y.; Xiong, D.; Guan, S.; Guo, B.H.; Mai, H.Q.; et al. Epstein-barr virus-encoded LMP2A induces an epithelial- mesenchymal transition and increases the number of side population stem-like cancer cells in nasopharyngeal carcinoma. PLoS Pathog. 2010, 6. [CrossRef] [PubMed]

131. Luo, B.; Wang, Y.; Wang, X.-F.; Liang, H.; Yan, L.-P.; Huang, B.-H.; Zhao, P. Expression of Epstein-Barr virus genes in EBV-associated gastric carcinomas. World J. Gastroenterol. 2005, 11, 629-633. [CrossRef] [PubMed]

132. Ohshima, K.; Haraoka, S.; Sugihara, M.; Suzumiya, J.; Kawasaki, C.; Kanda, M.; Kikuchi, M. Amplification and expression of a decoy receptor for Fas ligand (DcR3) in virus (EBV or HTLV-I) associated lymphomas. Cancer Lett. 2000, 160, 89-97. [CrossRef] 
133. Ho, C.-H.; Chen, C.-L.; Li, W.-Y.; Chen, C.-J. Decoy receptor 3, upregulated by Epstein-Barr virus latent membrane protein 1, enhances nasopharyngeal carcinoma cell migration and invasion. Carcinogenesis 2009, 30, 1443-1451. [CrossRef] [PubMed]

134. Falini, B.; Stein, H.; Pileri, S.; Canino, S.; Farabbi, R.; Martelli, M.F.; Grignani, F.; Fagioli, M.; Minelli, O.; Ciani, C. Expression of lymphoid-associated antigens on Hodgkin's and Reed-Sternberg cells of Hodgkin's disease. An immunocytochemical study on lymph node cytospins using monoclonal antibodies. Histopathology 1987, 11, 1229-1242. [CrossRef] [PubMed]

135. Horie, R.; Watanabe, T.; Morishita, Y.; Ito, K.; Ishida, T.; Kanegae, Y.; Saito, I.; Higashihara, M.; Mori, S.; Kadin, M.E.; et al. Ligand-independent signaling by overexpressed CD30 drives NF- $\kappa$ B activation in Hodgkin-Reed-Sternberg cells. Oncogene 2002, 21, 2493-2503. [CrossRef] [PubMed]

136. Pinto, A.; Aldinucci, D.; Gloghini, A.; Zagonel, V.; Degan, M.; Improta, S.; Juzbasic, S.; Todesco, M.; Perin, V.; Gattei, V.; et al. Human eosinophils express functional CD30 ligand and stimulate proliferation of a Hodgkin's disease cell line. Blood 1996, 88, 3299-3305.

137. Molin, D.; Fischer, M.; Xiang, Z.; Larsson, U.; Harvima, I.; Venge, P.; Nilsson, K.; Sundström, C.; Enblad, G.; Nilsson, G. Mast cells express functional CD30 ligand and are the predominant CD30L-positive cells in Hodgkin's disease. Br. J. Haematol. 2001, 114, 616-623. [CrossRef] [PubMed]

138. Gruss, H.J.; Hirschstein, D.; Wright, B.; Ulrich, D.; Caligiuri, M.A.; Barcos, M.; Strockbine, L.; Armitage, R.J.; Dower, S.K. Expression and function of CD40 on Hodgkin and Reed-Sternberg cells and the possible relevance for Hodgkin's disease. Blood 1994, 84, 2305-2314. [PubMed]

139. O'Grady, J.T.; Stewart, S.; Lowrey, J.; Howie, S.E.; Krajewski, A.S. CD40 expression in Hodgkin's disease. Am. J. Pathol. 1994, 144, 21-26. [PubMed]

140. Li, R.; Chen, W.-C.; Pang, X.-Q.; Hua, C.; Li, L.; Zhang, X.-G. Expression of CD40 and CD40L in Gastric Cancer Tissue and Its Clinical Significance. Int. J. Mol. Sci. 2009, 10, 3900-3917. [CrossRef] [PubMed]

141. Ohshima, K.; Karube, K.; Hamasaki, M.; Suefuji, H.; Tutiya, T.; Yamaguchi, T.; Suzumiya, J.; Kikuchi, M. Imbalances of chemokines, chemokine receptors and cytokines in Hodgkin lymphoma: Classical Hodgkin lymphomavs. Hodgkin-like ATLL. Int. J. Cancer 2003, 106, 706-712. [CrossRef] [PubMed]

142. Imadome, K.I.; Shimizu, N.; Yajima, M.; Watanabe, K.; Nakamura, H.; Takeuchi, H.; Fujiwara, S. CD40 signaling activated by Epstein-Barr virus promotes cell survival and proliferation in gastric carcinoma-derived human epithelial cells. Microbes Infect. 2009, 11, 429-433. [CrossRef] [PubMed]

143. Gires, O.; Zimber-Strobl, U.; Gonnella, R.; Ueffing, M.; Marschall, G.; Zeidler, R.; Pich, D.; Hammerschmidt, W. Latent membrane protein 1 of Epstein-Barr virus mimics a constitutively active receptor molecule. EMBO J. 1997, 16, 6131-6140. [CrossRef] [PubMed]

144. Skinnider, B.F. Signal transducer and activator of transcription 6 is frequently activated in Hodgkin and Reed-Sternberg cells of Hodgkin lymphoma. Blood 2002, 99, 618-626. [CrossRef] [PubMed]

145. Joos, S.; Küpper, M.; Ohl, S.; Cells, C.D.H.; Ku, M.; Von Bonin, F.; Mechtersheimer, G.; Bentz, M.; Marynen, P.; Mo, P.; et al. Genomic Imbalances Including Amplification of the Tyrosine Kinase Gene JAK2 in CD30+ Hodgkin Cells Advances in Brief Genomic Imbalances Including Amplification of the Tyrosine Kinase Gene JAK2 in cd30+ hodgkin cells. Cancer Res. 2000, 63, 549-552.

146. Gunawardana, J.; Chan, F.C.; Telenius, A.; Woolcock, B.; Kridel, R.; Tan, K.L.; Ben-Neriah, S.; Mottok, A.; Lim, R.S.; Boyle, M.; et al. Recurrent somatic mutations of PTPN1 in primary mediastinal B cell lymphoma and Hodgkin lymphoma. Nat. Genet. 2014, 46, 329-335. [CrossRef] [PubMed]

147. Weniger, M.A.; Melzner, I.; Menz, C.K.; Wegener, S.; Bucur, A.J.; Dorsch, K.; Mattfeldt, T.; Barth, T.F.E.; Möller, P. Mutations of the tumor suppressor gene SOCS-1 in classical Hodgkin lymphoma are frequent and associated with nuclear phospho-STAT5 accumulation. Oncogene 2006, 25, 2679-2684. [CrossRef] [PubMed]

148. Gires, O.; Kohlhuber, F.; Kilger, E.; Baumann, M.; Kieser, A.; Kaiser, C.; Zeidler, R.; Scheffer, B.; Ueffing, M.; Hammerschmidt, W. Latent membrane protein 1 of Epstein-Barr virus interacts with JAK3 and activates STAT proteins. EMBO J. 1999, 18, 3064-3073. [CrossRef] [PubMed]

149. Stewart, S.; Dawson, C.W.; Takada, K.; Curnow, J.; Moody, C.A.; Sixbey, J.W.; Young, L.S. Epstein-Barr virus-encoded LMP2A regulates viral and cellular gene expression by modulation of the NF-kappaB transcription factor pathway. Proc. Natl. Acad. Sci. USA 2004, 101, 15730-15735. [CrossRef] [PubMed]

150. Herbst, H.; Samol, J.; Foss, H.D.; Raff, T.; Niedobitek, G. Modulation of interleukin-6 expression in Hodgkin and Reed-Sternberg cells by Epstein-Barr virus. J. Pathol. 1997, 182, 299-306. [CrossRef] 
151. Liu, Y.; Sattarzadeh, A.; Diepstra, A.; Visser, L.; Van Den Berg, A. The microenvironment in classical Hodgkin lymphoma: An actively shaped and essential tumor component. Semin. Cancer Biol. 2014, 24, 15-22. [CrossRef] [PubMed]

152. Kis, L.L.; Gerasimčik, N.; Salamon, D.; Persson, E.K.; Nagy, N.; Klein, G.; Severinson, E.; Klein, E. STAT6 signaling pathway activated by the cytokines IL-4 and IL-13 induces expression of the Epstein-Barr virus-encoded protein LMP-1 in absence of EBNA-2: Implications for the type II EBV latent gene expression in Hodgkin lymphoma. Blood 2011, 117, 165-174. [CrossRef] [PubMed]

153. Tempera, I.; De Leo, A.; Kossenkov, A.V.; Cesaroni, M.; Song, H.; Dawany, N.; Showe, L.; Lu, F.; Wikramasinghe, P.; Lieberman, P.M. Identification of MEF2B, EBF1, and IL6R as Direct Gene Targets of Epstein-Barr Virus (EBV) Nuclear Antigen 1 Critical for EBV-Infected B-Lymphocyte Survival. J. Virol. 2016, 90, 345-355. [CrossRef] [PubMed]

154. Zhang, G.; Tsang, C.M.; Deng, W.; Yip, Y.L.; Lui, V.W.-Y.; Wong, S.C.C.; Cheung, A.L.-M.; Hau, P.M.; Zeng, M.; Lung, M.L.; et al. Enhanced IL-6/IL-6R signaling promotes growth and malignant properties in EBV-infected premalignant and cancerous nasopharyngeal epithelial cells. PLoS ONE 2013, 8, e62284. [CrossRef] [PubMed]

155. Liu, S.; Tsang, N. Leukemia inhibitory factor promotes nasopharyngeal carcinoma progression and radioresistance. J. Clin. Investig. 2013, 123, 5269-5283. [CrossRef] [PubMed]

156. Wang, N.; Wu, Q.-L.; Fang, Y.; Mai, H.-Q.; Zeng, M.-S.; Shen, G.-P.; Hou, J.-H.; Zeng, Y.-X. Expression of chemokine receptor CXCR4 in nasopharyngeal carcinoma: Pattern of expression and correlation with clinical outcome. J. Transl. Med. 2005, 3, 26. [CrossRef] [PubMed]

157. Xu, J.; Deng, X.; Tang, M.; Li, L.; Xiao, L.; Yang, L.; Zhong, J.; Bode, A.M.; Dong, Z.; Tao, Y.; et al. Tyrosylprotein Sulfotransferase-1 and Tyrosine Sulfation of Chemokine Receptor 4 Are Induced by Epstein-Barr Virus Encoded Latent Membrane Protein 1 and Associated with the Metastatic Potential of Human Nasopharyngeal Carcinoma. PLoS ONE 2013, 8. [CrossRef] [PubMed]

158. Li, J.; Zhang, X.S.; Xie, D.; Deng, H.X.; Gao, Y.F.; Chen, Q.Y.; Huang, W.L.; Masucci, M.G.; Zeng, Y.X. Expression of immune-related molecules in primary EBV positive Chinese nasopharyngeal carcinoma: Associated with latent membrane protein 1 (LMP1) expression. Cancer Biol. Ther. 2007, 6, 1997-2004. [CrossRef] [PubMed]

159. Chong, J.; Sakuma, K.; Sudo, M.; Osawa, T.; Ohara, E.; Uozaki, H.; Shibahara, J.; Kuroiwa, K.; Tominaga, S.; Hippo, Y.; et al. Interleukin-1beta expression in human gastric carcinoma with Epstein-Barr virus infection. J. Virol. 2002, 76, 6825-6831. [CrossRef] [PubMed]

160. Zhang, L.; MacIsaac, K.D.; Zhou, T.; Huang, P.-Y.; Xin, C.; Dobson, J.R.; Yu, K.; Chiang, D.Y.; Fan, Y.; Pelletier, M.R.; et al. Genomic Analysis of Nasopharyngeal Carcinoma Reveals TME-based Subtypes. Mol. Cancer Res. 2017, molcanres.0134.2017. [CrossRef] [PubMed]

161. Renné, C.; Hinsch, N.; Willenbrock, K.; Fuchs, M.; Klapper, W.; Engert, A.; Küppers, R.; Hansmann, M.L.; Bräuninger, A. The aberrant coexpression of several receptor tyrosine kinases is largely restricted to EBV-negative cases of classical Hodgkin's lymphoma. Int. J. Cancer 2007, 120, 2504-2509. [CrossRef] [PubMed]

162. Renné, C.; Willenbrock, K.; Küppers, R.; Hansmann, M.L.; Bräuninger, A. Autocrine- and paracrine-activated receptor tyrosine kinases in classic Hodgkin lymphoma. Blood 2005, 105, 4051-4059. [CrossRef] [PubMed]

163. Cader, F.Z.; Vockerodt, M.; Bose, S.; Nagy, E.; Brundler, M.A.; Kearns, P.; Murray, P.G. Lymphoid neoplasia: The EBV oncogene LMP1 protects lymphoma cells from cell death through the collagen-mediated activation of DDR1. Blood 2013, 122, 4237-4245. [CrossRef] [PubMed]

164. Teofili, L.; Di Febo, A.L.; Pierconti, F.; Maggiano, N.; Bendandi, M.; Rutella, S.; Cingolani, A.; Di Renzo, N.; Musto, P.; Pileri, S.; et al. Expression of the c-met proto-oncogene and its ligand, hepatocyte growth factor, in Hodgkin disease. Blood 2001, 97, 1063-1069. [CrossRef] [PubMed]

165. Xu, C.; Plattel, W.; van den Berg, A.; Rüther, N.; Huang, X.; Wang, M.; de Jong, D.; Vos, H.; van Imhoff, G.; Viardot, A.; et al. Expression of the c-Met oncogene by tumor cells predicts a favorable outcome in classical Hodgkin's lymphoma. Haematologica 2012, 97, 572-578. [CrossRef] [PubMed]

166. Qian, C.; Guo, X.; Cao, B.; Kort, E.J.; Lee, C.; Chen, J.; Wang, L.; Mai, W.; Min, H.; Hong, M.; et al. Met Protein Expression Level Correlates with Survival in Patients with Late-stage Nasopharyngeal Carcinoma Met Protein Expression Level Correlates with Survival in Patients with Late-stage Nasopharyngeal Carcinoma. Cancer Res. 2002, 589-596. 
167. Luo, B.; Wang, Y.; Wang, X.F.; Gao, Y.; Huang, B.H.; Zhao, P. Correlation of Epstein-Barr virus and its encoded proteins with Helicobacter pylori and expression of c-met and c-myc in gastric carcinoma. World J. Gastroenterol. 2006, 12, 1842-1848. [CrossRef] [PubMed]

168. Weimar, I.S.; Weijer, K.; Van Den Berk, P.C.M.; Muller, E.J.; Miranda, N.; Bakker, A.Q.; Heemskerk, M.H.M.; Hekman, A.; De Gast, G.C.; Gerritsen, W.R. HCF/SF and its receptor c-MET play a minor role in the dissemination of human B-lymphoma cells in SCID mice. Br. J. Cancer 1999, 81, 43-53. [CrossRef] [PubMed]

169. Lam, B.Q.; Dai, L.; Qin, Z. The role of HGF/c-MET signaling pathway in lymphoma. J. Hematol. Oncol. 2016, 9, 1-8. [CrossRef] [PubMed]

170. Van Der Voort, B.R.; Taher, T.E.I.; Keehnen, R.M.J.; Smit, L.; Groenink, M.; Pals, S.T. Paracrine Regulation of Germinal Center B Cell Adhesion through the c-Met-Hepatocyte Growth Factor/Scatter Factor Pathway. J. Exp. Med. 1997, 185, 2121-2131. [CrossRef] [PubMed]

171. Liang, Z.; Diepstra, A.; Xu, C.; Van Imhoff, G.; Plattel, W.; Van Den Berg, A.; Visser, L. Insulin-like growth factor 1 receptor is a prognostic factor in classical hodgkin lymphoma. PLoS ONE 2014, 9. [CrossRef] [PubMed]

172. Iwakiri, D.; Sheen, T.S.; Chen, J.Y.; Huang, D.P.; Takada, K. Epstein-Barr virus-encoded small RNA induces insulin-like growth factor 1 and supports growth of nasopharyngeal carcinoma-derived cell lines. Oncogene 2005, 24, 1767-1773. [CrossRef] [PubMed]

173. Iwakiri, D. Autocrine Growth of Epstein-Barr Virus-Positive Gastric Carcinoma Cells Mediated by an Epstein-Barr Virus-Encoded Small RNA Advances in Brief Autocrine Growth of Epstein-Barr Virus-Positive Gastric Carcinoma Cells. Cancer Res. 2003, 63, 7062-7067. [PubMed]

174. Houldcroft, C.J.; Kellam, P. Host genetics of Epstein-Barr virus infection, latency and disease. Rev. Med. Virol. 2015, 25, 71-84. [CrossRef] [PubMed]

175. Yasui, Y.; Hamajima, N.; Nakamura, T.; El-Din, N.S.; Tajima, K.; Potter, J.D. Association of Epstein-Barr virus antibody titers with a human IL-10 promoter polymorphism in Japanese women. J. Autoimmune Dis. 2008, 5, 1-5. [CrossRef] [PubMed]

176. Rubicz, R.; Yolken, R.; Drigalenko, E.; Carless, M.A.; Dyer, T.D.; Bauman, L.; Melton, P.E.; Kent, J.W.; Harley, J.B.; Curran, J.E.; et al. A Genome-Wide Integrative Genomic Study Localizes Genetic Factors Influencing Antibodies against Epstein-Barr Virus Nuclear Antigen 1 (EBNA-1). PLoS Genet. 2013, 9. [CrossRef] [PubMed]

177. Pedergnana, V.; Syx, L.; Cobat, A.; Guergnon, J.; Brice, P.; Fermé, C.; Carde, P.; Hermine, O.; Le- Pendeven, C.; Amiel, C.; et al. Combined linkage and association studies show that HLA class II variants control levels of antibodies against Epstein-Barr virus antigens. PLoS ONE 2014, 9, 1-5. [CrossRef] [PubMed]

178. Mandage, R.; Telford, M.; Rodríguez, J.A.; Farré, X.; Layouni, H.; Marigorta, U.M.; Cundiff, C.; Heredia-Genestar, J.M.; Navarro, A.; Santpere, G. Genetic factors affecting EBV copy number in lymphoblastoid cell lines derived from the 1000 Genome Project samples. PLoS ONE 2017, 12, 1-19. [CrossRef] [PubMed]

179. Diepstra, A.; Niens, M.; Vellenga, E.; Van Imhoff, G.W.; Nolte, I.M.; Schaapveld, M.; Van Der Steege, G.; Van Den Berg, A.; Kibbelaar, R.E.; Te Meerman, G.J.; et al. Association with HLA class I in Epstein-Barrvirus-positive and with HLA class III in Epstein-Barr-virus-negative Hodgkin's lymphoma. Lancet 2005, 365, 2216-2224. [CrossRef]

180. Urayama, K.Y.; Jarrett, R.F.; Hjalgrim, H.; Diepstra, A.; Kamatani, Y.; Chabrier, A.; Gaborieau, V.; Boland, A.; Nieters, A.; Becker, N.; et al. Genome-Wide Association Study of Classical Hodgkin Lymphoma and Epstein-Barr Virus Status-Defined Subgroups. J. Natl. Cancer Inst. 2012, 104, 240-253. [CrossRef] [PubMed]

181. Cozen, W.; Li, D.; Best, T.; Van Den Berg, D.J.; Gourraud, P.; Victoria, K.; Skol, A.D.; Mack, T.M.; Glaser, S.L.; Weiss, L.M.; et al. A genome-wide meta-analysis of nodular sclerosis Hodgkin lymphoma identifies risk loci at 6p21. 32. Boold 2011, 119, 1-3. [CrossRef]

182. Niens, M.; Jarrett, R.F.; Hepkema, B.; Nolte, I.M.; Diepstra, A.; Platteel, M.; Kouprie, N.; Delury, C.P.; Gallagher, A.; Visser, L.; et al. HLA-A*02 is associated with a reduced risk and HLA-A*01 with an increased risk of developing EBV+ Hodgkin lymphoma. Blood 2007, 110, 3310-3315. [CrossRef] [PubMed]

183. Hjalgrim, H.; Rostgaard, K.; Johnson, P.C.D.; Lake, A.; Shield, L.; Little, A.-M.; Ekstrom-Smedby, K.; Adami, H.-O.; Glimelius, B.; Hamilton-Dutoit, S.; et al. HLA-A alleles and infectious mononucleosis suggest a critical role for cytotoxic T-cell response in EBV-related Hodgkin lymphoma. Proc. Natl. Acad. Sci. USA 2010, 107, 6400-6405. [CrossRef] [PubMed] 
184. Johnson, P.C.D.; McAulay, K.A.; Montgomery, D.; Lake, A.; Shield, L.; Gallagher, A.; Little, A.M.; Shah, A.; Marsh, S.G.E.; Taylor, G.M.; et al. Modeling HLA associations with EBV-positive and -negative Hodgkin lymphoma suggests distinct mechanisms in disease pathogenesis. Int. J. Cancer 2015, 137, 1066-1075. [CrossRef] [PubMed]

185. Jones, K.; Wockner, L.; Brennan, R.M.; Keane, C.; Chattopadhyay, P.K.; Roederer, M.; Price, D.A.; Cole, D.K.; Hassan, B.; Beck, K.; et al. The impact of HLA class I and EBV latency-II antigen-specific CD8 + T cells on the pathogenesis of EBV + Hodgkin lymphoma. Clin. Exp. Immunol. 2016, 183, 206-220. [CrossRef] [PubMed]

186. Huang, X.; Hepkema, B.; Nolte, I.; Kushekhar, K.; Jongsma, T.; Veenstra, R.; Poppema, S.; Gao, Z.; Visser, L.; Diepstra, A.; et al. HLA-A*02:07 is a protective allele for EBV negative and a susceptibility allele for EBV positive classical Hodgkin lymphoma in China. PLoS ONE 2012, 7, 1-5. [CrossRef] [PubMed]

187. Bei, J.-X.; Li, Y.; Jia, W.-H.; Feng, B.-J.; Zhou, G.; Chen, L.-Z.; Feng, Q.-S.; Low, H.-Q.; Zhang, H.; He, F.; et al. A genome-wide association study of nasopharyngeal carcinoma identifies three new susceptibility loci. Nat. Genet. 2010, 42, 599-603. [CrossRef] [PubMed]

188. Chin, Y.M.; Mushiroda, T.; Takahashi, A.; Kubo, M.; Krishnan, G.; Yap, L.F.; Teo, S.H.; Lim, P.V.H.; Yap, Y.Y.; Pua, K.C.; et al. HLA-A SNPs and amino acid variants are associated with nasopharyngeal carcinoma in Malaysian Chinese. Int. J. Cancer 2015, 136, 678-687. [CrossRef] [PubMed]

189. Lu, S.J. Linkage of a nasopharyngeal carcinoma susceptibility locus to the HLA region. Nature 1990, 346, 470-471. [CrossRef] [PubMed]

190. Zhao, M.; Cai, H.; Li, X.; Zheng, H.; Yang, X.; Fang, W.; Zhang, L.; Wei, G.; Li, M.; Yao, K.; et al. Further evidence for the existence of major susceptibility of nasopharyngeal carcinoma in the region near HLA-A locus in Southern Chinese. J. Transl. Med. 2012, 10. [CrossRef] [PubMed]

191. Tang, M.; Lautenberger, J.A.; Gao, X.; Sezgin, E.; Hendrickson, S.L.; Troyer, J.L.; David, V.A.; Guan, L.; McIntosh, C.E.; Guo, X.; et al. The principal genetic determinants for nasopharyngeal carcinoma in China involve the HLA class I antigen recognition groove. PLoS Genet. 2012, 8, e1003103. [CrossRef] [PubMed]

192. Hsu, W.L.; Tse, K.P.; Liang, S.; Chien, Y.C.; Su, W.H.; Yu, K.J.; Cheng, Y.J.; Tsang, N.M.; Hsu, M.M.; Chang, K.P.; et al. Evaluation of human leukocyte antigen-a (HLA-A), other NON-HLA markers on chromosome 6p21 and risk of nasopharyngeal carcinoma. PLoS ONE 2012, 7, 4-9. [CrossRef] [PubMed]

193. Tse, K.-P.; Su, W.-H.; Chang, K.-P.; Tsang, N.-M.; Yu, C.-J.; Tang, P.; See, L.-C.; Hsueh, C.; Yang, M.-L.; Hao, S.-P.; et al. Genome-wide Association Study Reveals Multiple Nasopharyngeal Carcinoma-Associated Loci within the HLA Region at Chromosome 6p21.3. Am. J. Hum. Genet. 2009, 85, 194-203. [CrossRef] [PubMed]

194. Ng, C.C.; Yew, P.Y.; Puah, S.M.; Krishnan, G.; Yap, L.F.; Teo, S.H.; Lim, P.V.H.; Govindaraju, S.; Ratnavelu, K.; Sam, C.K.; et al. A genome-wide association study identifies ITGA9 conferring risk of nasopharyngeal carcinoma. J. Hum. Genet. 2009, 54, 392-397. [CrossRef] [PubMed]

195. Hutt-Fletcher, L.M.; Chesnokova, L.S. Integrins as triggers of Epstein-Barr virus fusion and epithelial cell infection. Virulence 2010, 1, 395-398. [CrossRef] [PubMed]

196. Sousa, H.; Breda, E.; Santos, A.M.; Catarino, R.; Pinto, D.; Canedo, P.; Machado, J.C.; Medeiros, R. IL-1RN VNTR polymorphism as a susceptibility marker for nasopharyngeal carcinoma in Portugal. Arch. Oral Biol. 2013, 58, 1040-1046. [CrossRef] [PubMed]

197. Cui, Q.; Feng, Q.-S.; Mo, H.-Y.; Sun, J.; Xia, Y.-F.; Zhang, H.; Foo, J.N.; Guo, Y.-M.; Chen, L.-Z.; Li, M.; et al. An extended genome-wide association study identifies novel susceptibility loci for nasopharyngeal carcinoma. Hum. Mol. Genet. 2016, 25, 3626-3634. [CrossRef] [PubMed]

198. Bei, J.X.; Su, W.H.; Ng, C.C.; Yu, K.; Chin, Y.M.; Lou, P.J.; Hsu, W.L.; McKay, J.D.; Chen, C.J.; Chang, Y.S.; et al. A GWAS meta-analysis and replication study identifies a novel locus within CLPTM1L/TERT associated with nasopharyngeal carcinoma in individuals of Chinese ancestry. Cancer Epidemiol. Biomarkers Prev. 2016, 25, 188-192. [CrossRef] [PubMed]

199. Dai, W.; Zheng, H.; Cheung, A.K.L.; Tang, C.S.; Ko, J.M.Y.; Wong, B.W.Y.; Leong, M.M.L.; Sham, P.C.; Cheung, F.; Kwong, D.L.-W.; et al. Whole-exome sequencing identifies MST1R as a genetic susceptibility gene in nasopharyngeal carcinoma. Proc. Natl. Acad. Sci. USA 2016, 113, 3317-3322. [CrossRef] [PubMed]

200. Koriyama, C.; Shinkura, R.; Hamasaki, Y.; Fujiyoshi, T.; Eizuru, Y.; Tokunaga, M. Human leukocyte antigens related to Epstein-Barr virus-associated gastric carcinoma in Japanese patients. Eur. J. Cancer Prev. 2001, 10, 69-75. [CrossRef] [PubMed] 
201. Wu, M.-S.; Huang, S.-P.; Chang, Y.-T.; Shun, C.-T.; Chang, M.-C.; Lin, M.-T.; Wang, H.-P.; Lin, J.-T. Tumor necrosis factor- $\alpha$ and interleukin-10 promoter polymorphisms in Epstein-Barr virus-associated gastric carcinoma. J. Infect. Dis. 2002, 185, 106-109. [CrossRef] [PubMed]

202. Kuang, X.; Sun, L.; Liu, S.; Zhao, Z.; Zhao, D.; Liu, S.; Luo, B. Association of single nucleotide polymorphism rs2065955 of the filaggrin gene with susceptibility to Epstein-Barr virus-associated gastric carcinoma and EBV-negative gastric carcinoma. Virol. Sin. 2016, 31, 306-313. [CrossRef] [PubMed]

203. Zhao, D.; Liu, S.; Sun, L.; Zhao, Z.; Liu, S.; Kuang, X.; Shu, J.; Luo, B. Glypican-4 gene polymorphism (rs1048369) and susceptibility to Epstein-Barr virus-associated and -negative gastric carcinoma. Virus Res. 2016, 220, 52-56. [CrossRef] [PubMed]

C 2018 by the authors. Licensee MDPI, Basel, Switzerland. This article is an open access article distributed under the terms and conditions of the Creative Commons Attribution (CC BY) license (http:/ / creativecommons.org/licenses/by/4.0/). 